\title{
PARAÍSO: UMA DESCOBERTA INTERNA
}

\author{
Mestranda: Maria Fernanda Alves Eva \\ Orientador: Prof. Dr. Geraldo Souza Dias
}

Dissertação apresentada como
requisito parcial à obtenção do
grau de Mestre em Poéticas
Visuais, no Programa de Pós-
Graduação da Escola de
Comunicação e Artes, na
Universidade de São Paulo.

UNIVERSIDADE DE SÃO PAULO

São Paulo 
Banca Examinadora: 
Dedico este trabalho a minha família.

Gostaria de agradecer:

Ao Edi, que me propiciou uma vida tranquila para poder criar e fazer arte. Sem ele não teria me tornado artista. Meu amor eterno.

De coração ao Duda Rosa que me ajudou a corrigir erros, esticar as telas e caminha ao meu lado com muita paciência. Sem ele estaria louca.

Todos os meus amigos que sempre observam minhas obras, dão palpites, percebem erros, tecem elogios, me inspiram como o Claudio Lorenzo e a Sandra Martinelli.

Em especial a Fátima Putnoki que me levou pela mão para as primeiras aulas de pintura, a Lucila Meirelles grande aquisição desse mestrado, a Márcia Ferrão e ao Naum Simão que me ajudaram no texto.

A Keila Kern que me trouxe para esta universidade.

Todos os professores que me ensinaram o que sei.

Ao Mario Ramiro e a Carmen Aranha pela orientação indispensável na qualificação. Sem eles não chegaria a este resultado.

E por último, o mais importante, meu orientador Geraldo de Souza Dias que me mostrou o Paraíso que eu não havia avistado antes. 


\title{
SUMÁRIO
}

\author{
RESUMO
}

ABSTRACT

INTRODUÇÃO

1- PINTURAS DE PAISAGENS, DE ANIMAIS E O ELEMENTO PSÍQUICO

2 - HENRI ROSSEAU

3 - SÉRIE "RETRATOS GIGANTES"

4 - LUCIAN FREUD

5 - SÉRIE "ANIMAIS DA ARTE"

6 - A FOTOGRAFIA

7 - CONSTRUÇÃO DA POÉTICA DA SÉRIE "PARAÍSOS"

8 - CONSIDERAÇÕES FINAIS

9 - REFERÊNCIAS BIBLIOGRÁFICAS 


\section{RESUMO}

Esta dissertação é uma análise do processo de criação das séries "Retratos Gigantes", "Animais da Arte" e "Paraísos", e suas relações com a temática do Paraíso. São três conjuntos de pinturas que foram executadas em um período de três anos. O texto é complementar a estas pinturas e visa permitir uma abordagem das reflexões que geraram estas imagens, tendo como foco principal a série de pinturas intitulada "Paraísos". Na minha pesquisa teórica, busquei aprofundar e compreender a influência que tive principalmente de dois pintores, o francês Henry Rousseau e o inglês Lucian Freud. Rousseau contribuiu para uma liberdade no uso cromático, enquanto Freud suscitou reflexões de linguagem no que concerne à representação do corpo e de elementos psicológicos.

\section{ABSTRACT}

This dissertation is an analysis of the creative process involved in the "Giant Portraits", the "Animals in Art" and the "Paradises" series of paintings, and how they each relate to the theme of paradise. There are three groups of paintings that were done over a three-year period. The text complements the paintings and aims to assist one to approach the reflections that generated the images, having, as its principle focus, the "Paradises" series of paintings. In this theoretical search, I wanted to take a deeper look to better understand the two painters that influenced me most: the Frenchman Henry Rousseau and the Englishman Lucian Freud. Rousseau contributed towards a more liberal use of color, whereas Freud suscitated a reflection upon the language used in the representation of both the body and the pictures' psychological elements. 


\section{INTRODUÇÃO}

De acordo com Harold Rosenberg, filósofo e crítico de arte, “(...) a arte é essencialmente criação. Qualquer coisa pode ser uma obra de arte, mas o modo de produzi-la é que decide seu significado e seu valor" ${ }^{1}$. Sendo assim, minha pesquisa baseia-se na análise e na demonstração do meu processo de criação em pintura, prática principal da minha produção em Artes Visuais. Para tanto, a proposta é contextualizar essas pinturas, indicando minhas referências teóricas e os pintores que fortemente influenciaram esses trabalhos. Mesmo que não me limitando aos aspectos subjetivos do meu processo de criação artística, proponho nesta dissertação investigar sua atuação determinante, impulsionando com isto uma evolução provinda do entrecruzamento da prática criativa e da reflexão teórica.

Um desses aspectos de escolha subjetiva foi a dedicação ao tema específico das paisagens e, posteriormente, aos retratos, que juntos criaram a poética das pinturas da série "Paraísos", para a qual passei por um período de observação e exercícios visando o domínio das técnicas pertinentes a esses temas.

\footnotetext{
${ }^{1}$ Rosenberg, Harold, "O objeto ansioso" trad. Vera Pereira - São Paulo: Cosac\& Naif, 2004. p. 260.
} 


\section{PINTURAS DE PAISAGENS, DE ANIMAIS E O ELEMENTO PSÍQUICO}

Só inicio um quadro quando minha visão é comovida com algum objeto do mundo, seja real ou imaginário. O pensamento reflexivo para esta criação é motivado principalmente por meio de imagens. Essa reflexão motivada ainda é não verbal, e sim imagética, posto que se dá a partir de imagens figurativas. Através da percepção da luz, da cor e da profundidade dessas imagens geradoras e propulsoras, produz-se um eco em meu corpo, efeito fenomenológico de que trata o filosofo Merleau-Ponty. Tais imagens me despertam os sentidos, que resultam em uma nova imagem que projeto com tinta acrílica sobre a tela: a pintura.

Minha pesquisa sobre os processos de pintar iniciou com a realização de um vídeo, intitulado "Por que o artista contemporâneo ainda pinta?". ${ }^{2}$ Através desta nova forma de expressão como suporte, mostro a execução de uma pintura, em que entre uma paisagem figura um puma, acompanhado de depoimentos de diversas pessoas a respeito do assunto. Dando continuidade a essa pesquisa, realizei outro vídeo, com questões mais técnicas, intitulado "Por que o artista soteropolitano ainda pinta?", entrevistando pintores de Salvador BA, na ocasião do Salão de Arte Moderna do MAM, de que tive a oportunidade de participar. Através da observação da experiência do outro, pude concluir que a motivação que leva o artista contemporâneo a ainda produzir pinturas é quase sempre íntima e passional, trazendo à tona questões da psique que movem cada artista.

No caso das minhas pinturas, indaguei-me qual seria o motivo pictórico, a princípio, que me estimulara a tê-las criado, e detectei que foram predominantemente paisagens. Viajei a diversos lugares de preservação ambiental no Brasil, onde havia florestas primárias e secundárias, paisagens

${ }^{2}$ Disponível na internet: http://www.youtube.com/watch?v=N_EfbfSPXZU 
exuberantes e de tal modo afastadas dos grandes centros que transmitiam a sensação de uma experiência exclusiva. Assim, neste primeiro contato com esses ambientes é que surgiram as imagens que se tornaram propulsoras destas minhas séries de pinturas, já representando o Paraíso.

O poeta simbolista francês Charles Baudelaire, no texto crítico relativo ao Salão de 1859, em Paris, afirmou: "Se uma composição de árvores, montanhas, cursos d'água e casas, a que chamamos paisagem, é bela, não o é por si mesma, mas por mim, por minha própria graça, pela idéia ou sentimento que a ela associo". ${ }^{3}$ Assim, as paisagens, pela sua própria natureza, há séculos são ao mesmo tempo fonte de inspiração e plano de expressão do pintor. Capturando elementos da realidade dos lugares por onde viajei, compus as primeiras pinturas de paisagens e animais, ressignificando-os no espaço da tela.

Segundo Roger Piles, pintor e gravador francês do séc. XVII, a priori, a execução da paisagem pressupõe a observação de regras da perspectiva para efeito de verossimilhança. Essa atenção dada à perspectiva terá reverberações na composição cromática da tela, já que "quanto mais próximas do chão, maiores e mais verdes são as folhas das árvores, porque estão em posição de receber abundantemente a seiva que as alimenta". ${ }^{4} \mathrm{O}$ pintor ainda aponta os elementos específicos que dão "alma" à paisagem, sendo cinco: "as figuras, os animais, a água, as árvores agitadas pelo vento e a leveza do pincel". ${ }^{5}$ Referese ainda à "imitação fiel de cada caráter em particular" ${ }^{6}$

Nestes meus trabalhos não assumi nenhum compromisso com esses objetivos classicistas de verossimilhança e fidedignidade, sendo que tomei a realidade apenas como base referencial para a criação de paraísos inventados.

\footnotetext{
${ }^{3}$ BAUDELAIRE, Charles. A paisagem. Salão de 1859. In LICHTENSTEIN, J. (org.) A Pintura. V. 10. São Paulo: Ed. 34, 2006. p.124

${ }^{4}$ PILES, Roger de. Da paisagem. Curso de Pintura por Princípios. In LICHTENSTEIN, J. A Pintura. V. 10. São Paulo: Ed. 34, 2006. p. 61.

${ }^{5}$ Ibidem. p. 61.

${ }^{6}$ Ibidem. p. 63.
} 
Produzi quinze pinturas, em tinta acrílica sobre tela, de grandes dimensões, em média 200 x $300 \mathrm{~cm}$, que constituem a série "Paisagens", que retrata ambientes externos, como florestas, em que figuram diversos animais. Essas personagens aparecem em ambientes particulares, construídos a partir de fotografias que tirei nessas viagens pelo Brasil e complementadas com elementos imaginativos. Essas telas foram, inicialmente, compostas com muitos elementos e com a massa pictórica formada por pinceladas "pensadas" e muito contidas. Esse aspecto se transforma no decorrer dessa pesquisa, como veremos mais adiante, pois além do entendimento da produção, outro objetivo foi compreender a evolução do processo técnico que adquiriu novos modos de feitura.

As figuras dos animais apresentam-se sempre destacadas do fundo por meio de uma pintura diferenciada: mais detalhada e com contornos. Ora proporcionam sensações agradáveis, ora suscitam sua essência selvagem, imbuindo os outros personagens com suas características.

No intuito de retratar relações psicológicas, estas obras trazem expressões entre os personagens da cena, que por meio de olhares e posições revelam tais relações: uma expressa o medo de ser a presa, outra apresenta uma figura que espreita o espectador; uma traz um romance entre aves, outra tem sugestão de sentimentos como desinteresse, amor, entre outros. Enfim, são explicitadas as sensações desses personagens, por vezes sensações delicadas e singelas para animais tão selvagens.

Nestas telas, procuro atribuir uma humanização dos animais selvagens. Retrato-os como se fossem pessoas, preocupando-me com seus gestos e expressões, acabo por imprimir-Ihes um caráter humano, uma personalidade.

Outro aspecto na produção dessas pinturas é "o modo de utilização dos títulos, sem que estes venham a ser uma descrição do que está contido na tela" ${ }^{7}$ como afirmou Marcel Duchamp. O título deve ser um complemento de seu

\footnotetext{
${ }^{7}$ DUCHAMP, Marcel. In: PAZ, Octavio. Marcel Duchamp ou O castelo da pureza. Tradução Sebastião Uchoa Leite. São Paulo: Perspectiva, 2008. p. 57.
} 
conteúdo, com acréscimo de valores e de significados na percepção do quadro, sendo determinante para que se complete a ironia, tendencia sempre presente nas minhas obras, que quero criar com a imagem. Essa característica se mantém ao longo das obras, em títulos tais como: Família animal (fig. 1), Maternidade (fig. 2), Pantanal (fig. 3), Sossego, Hora do almoço, entre outros.

No momento inicial da produção, tratei apenas de retratar o meu entorno, as paisagens e animais que habitam a natureza paradisíaca. Durante o desenvolver deste estudo passei a manifestar o psicológico em relação a outras pessoas e, por fim, a ironia se voltará para mim mesma, ao me retratar como a Eva (personagem bíblica) em um paraíso inventado.

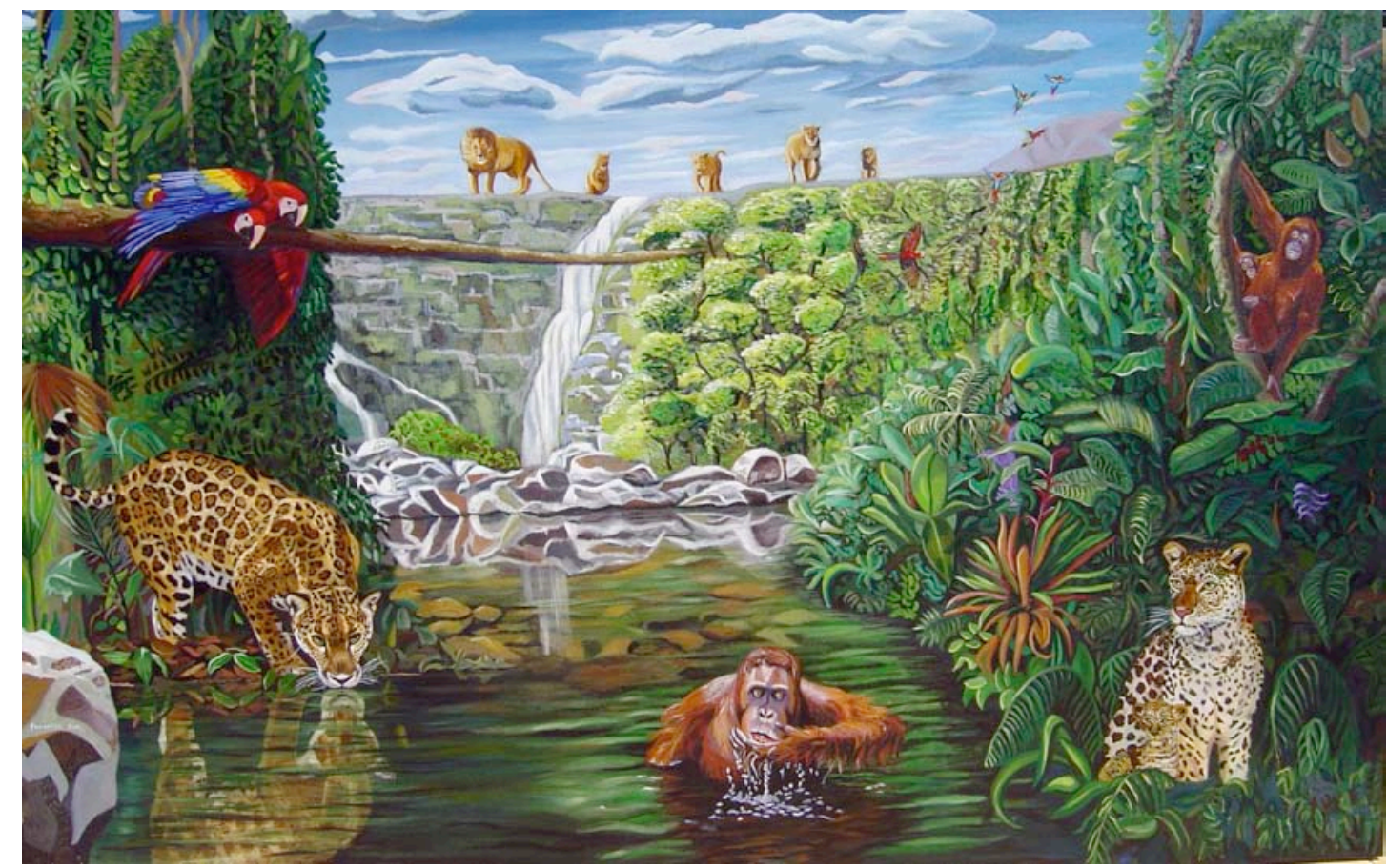

Fig. 1 - Fernanda Eva - "Família Animal”, 2006

Tinta acrílica sobre tela, $200 \times 300 \mathrm{~cm}$ 


\section{2 - HENRI ROUSSEAU}

Essas minhas primeiras produções de paisagens são muito coloridas e encontro relação nas paisagens do pintor parisiense Henri Rousseau (18441910). Segundo Argan, Rousseau surge num momento histórico

(...) em que a arte se qualifica como atividade intelectual do nível mais elevado, quando se sente a necessidade de distinguila da cultura oficial ou burguesa por uma característica própria de espontaneidade criativa; afirma-se, em suma, que a arte pode existir mesmo sem, mesmo contra 'aquela' cultura. Do culto romântico pela arte medieval, indevidamente definida como 'primitiva', passa-se ao interesse pelo artista inculto, ingênuo, popular (...). Rousseau (...) recoloca a arte em seu pedestal, manifesta frente a ela a ilimitada admiração do ignorante, do primitivo, pelos grandes valores do espírito. ${ }^{8}$

Ainda com Argan, Rousseau não foi um caso exato de artista inculto, mas sim um autodidata. Sobre sua pintura, o crítico e historiador da arte afirma: "É justamente a serenidade da execução cuidadosa, da delicada escolha das cores, da descrição atenta, que confere à visão a certeza de um mito realizado". ${ }^{9}$ Ao tratar do Cubismo, o crítico ainda se refere a Rousseau como um pintor fundamental na "determinação desse movimento revolucionário", que foi "a primeira pesquisa analítica sobre a estrutura funcional da obra de arte". ${ }^{10}$

Sendo assim, esse traço de um cromatismo calmo ligado à paisagem, em Rousseau, é um ponto de influência em meu trabalho. Outros aspectos de sua composição, que busquei assimilar, foi a ordenação estranha, um tanto artificial de suas figuras, que seguem uma hierarquia não ortodoxa, e também essa

\footnotetext{
${ }^{8}$ ARGAN, Giulio Carlo. Arte Moderna. Tradução Denise Bottmann e Federico Carotti. 4a Reimp. São Paulo: Companhia das Letras, 1992. p. 134

${ }^{9}$ Idem, Ibidem, p. 135

${ }^{10}$ Idem, bidem, p. 302
} 
"descrição atenta", de que trata Argan, que transmite essa idéia de "mito realizado" e abre ao olhar uma perspectiva do fantástico e do fantasioso.

$\mathrm{Na}$ maioria das vezes trago naturalmente esta exuberância única e selvagem para as obras, para retratar lugares do Brasil, tais como os rios Solimões e Badajós, na bacia Amazônica; rios São Benedito e Azul, no Sul do Pará, também na bacia Amazônica; rios Miranda, Paraguai e Negro, no Pantanal; e no complexo Estuário Lagunar de Iguape - Paranaguá (Pedrinhas, Porto Cubatão e Baia dos Pinheiros).

Inspirada em Rousseau, busco fazer um livre uso da perspectiva, da não obediência às regras técnicas que visam uma perfeição da proporção entre os planos. Portanto, a ilusão óptica não faz parte dos objetivos a serem alcançados: todos os progressos técnicos neste campo são conscientemente desrespeitados. Sobre a superfície plana da tela são colocados elementos "flutuantes", deslocados do seu contexto espacial.

Em todas as séries que apresento não há o uso de proporções precisas, naturalistas: aqui a pintura é guiada pelo sentimento e por uma noção própria de equilíbrio da composição estética. Não existe a preocupação em manter uma escala verossímil entre o ambiente e os elementos que compõem a cena. Trabalho com uma perspectiva incerta que induz o olhar a procurar um lugar distante, para o qual não se sabe se será efetivamente conduzido ou se encontrará algo inesperado.

Outro aspecto da influência de Rousseau nestas telas é o seu modo intuitivo, em que utilizo a técnica que mais se adapta a determinado objeto, sendo que numa mesma obra os tipos de pinceladas apresentam variação. Em especial tem importância a relação entre as cores e a variedade de estilos dentro de uma única obra, a maneira como elas se contrastam ao longo da tela, de elemento para elemento, o que ocorre na série "Paisagens". 


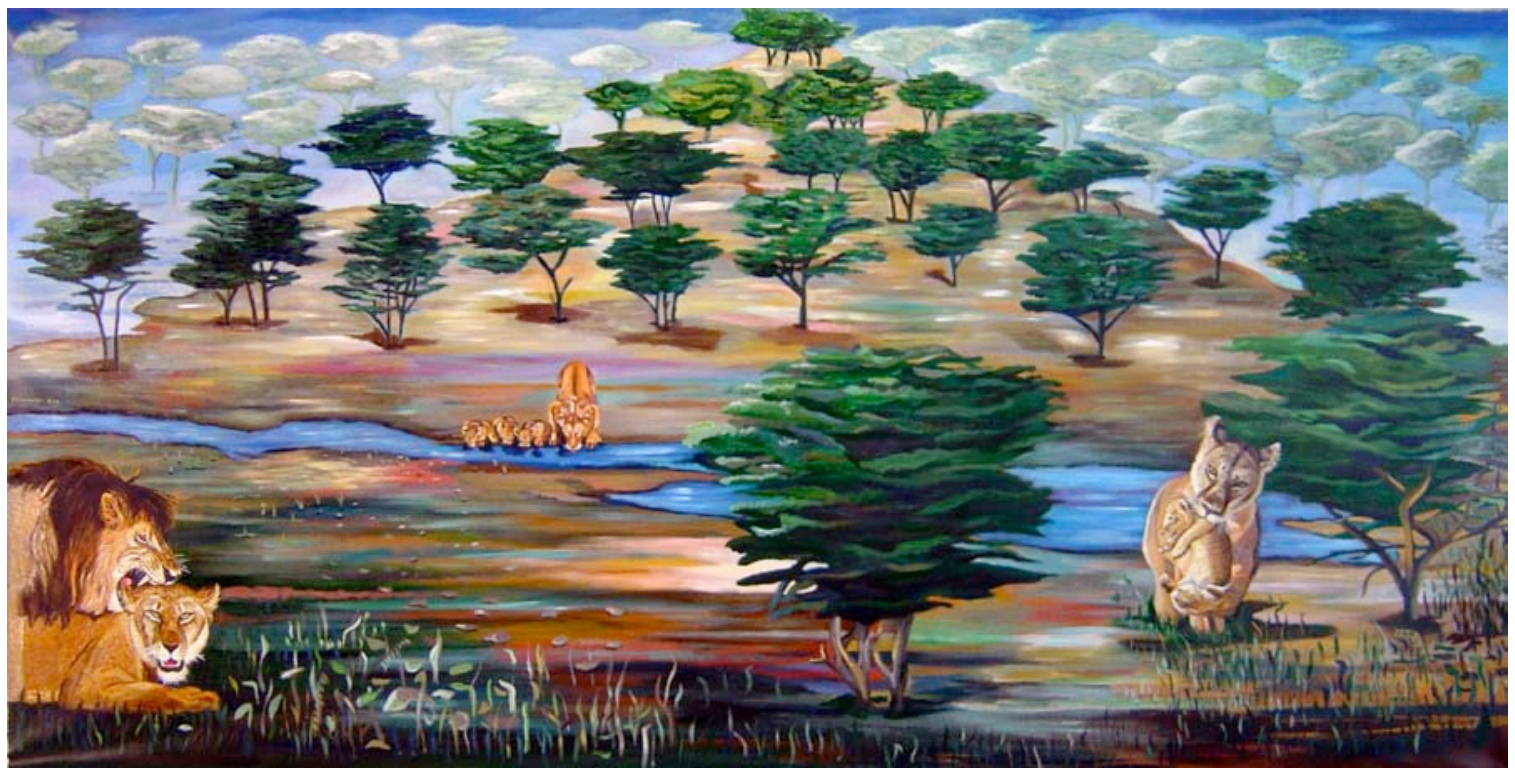

Fig. 2 - Fernanda Eva - "Maternidade”, 2007

Tinta acrílica sobre tela, $150 \times 300 \mathrm{~cm}$

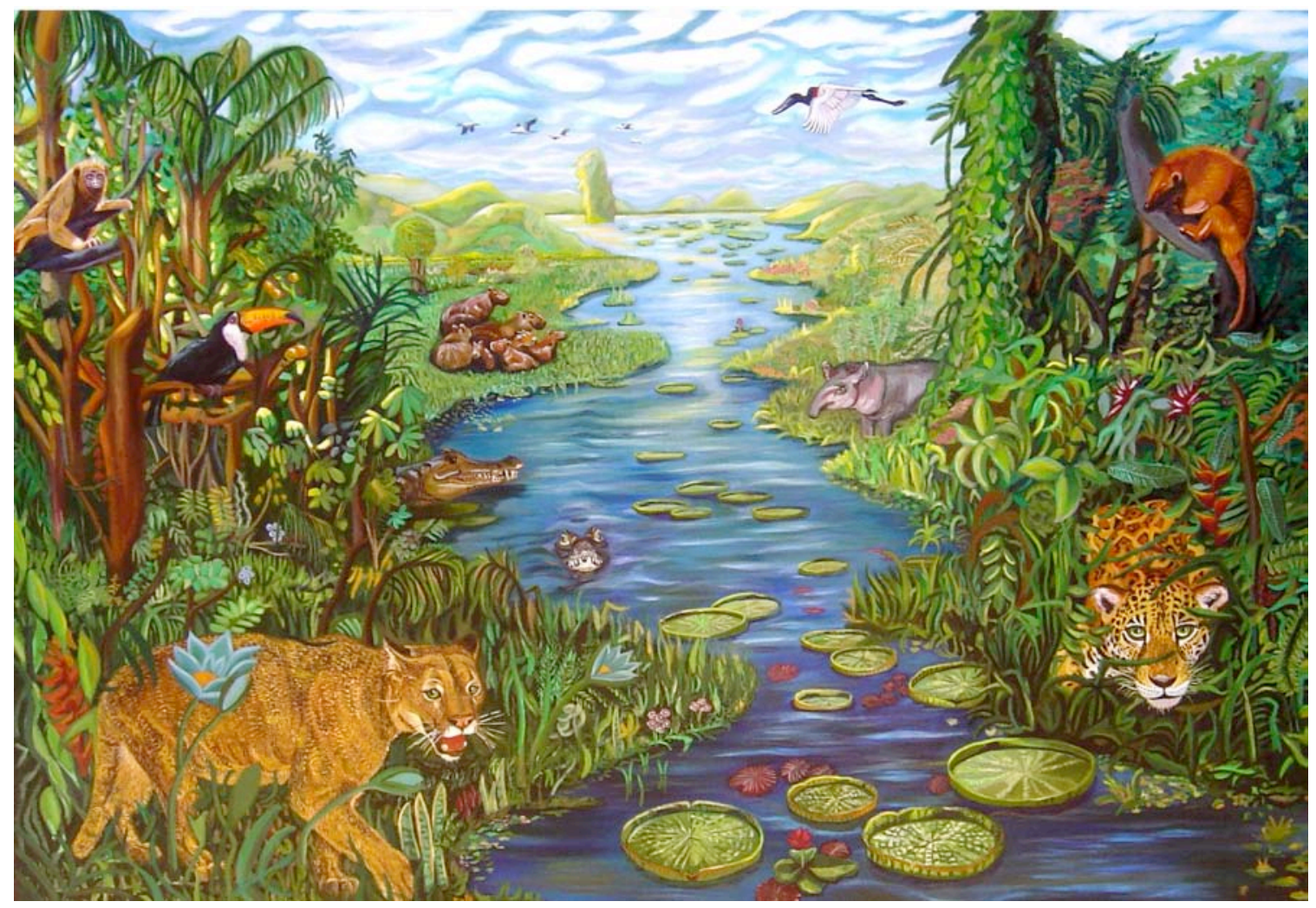

Fig. 3 - Fernanda Eva - "Pantanal”, 2006

Tinta acrílica sobre tela, $185 \times 270 \mathrm{~cm}$ 


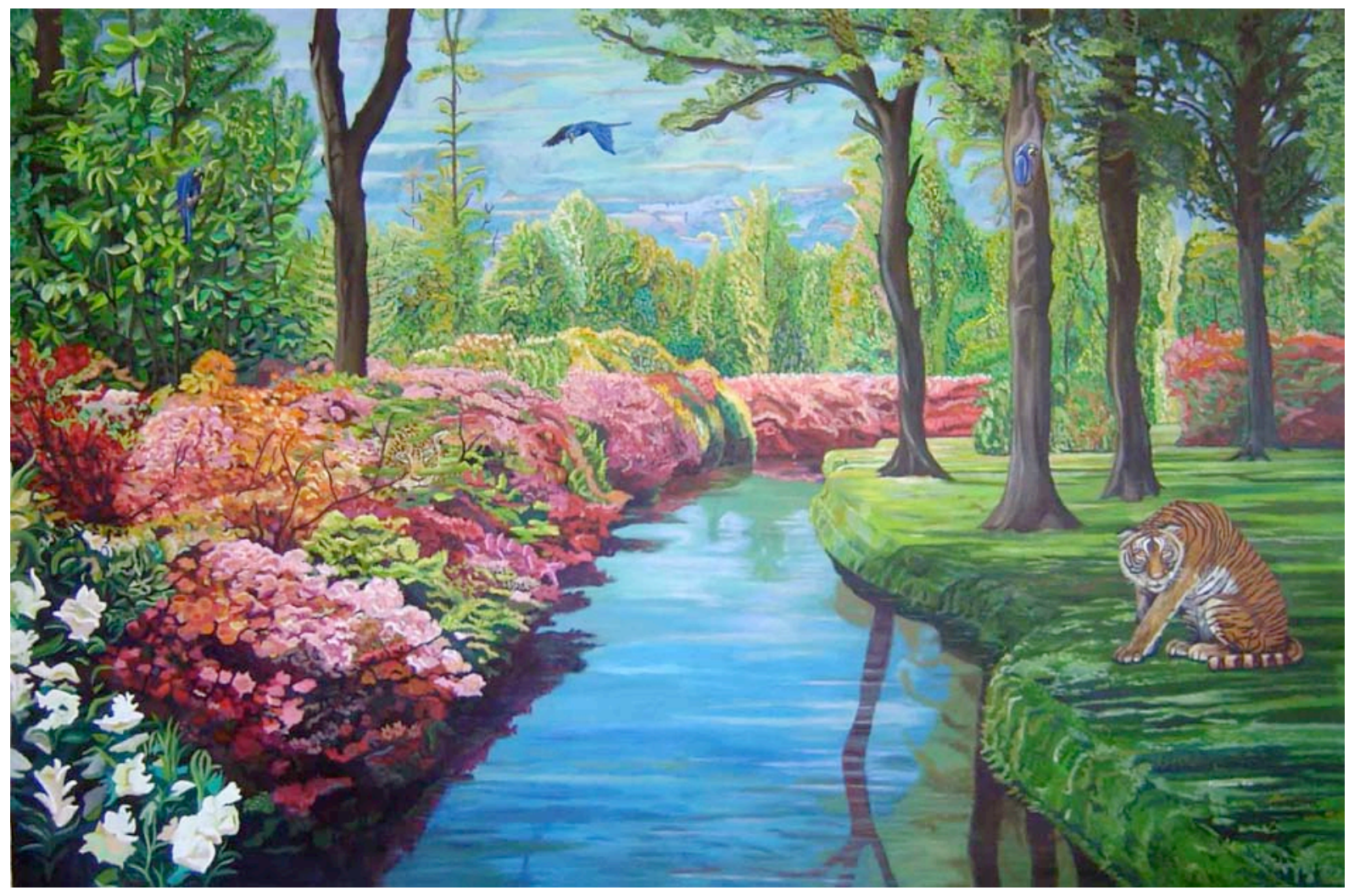

Fig. 4 - Fernanda Eva - “Quem invade o Paraíso?”, 2007

Acrílica sobre tela, $200 \times 300 \mathrm{~m}$

Nestas paisagens estou sempre narrando estórias inventadas. Na última tela desta série "Paisagens", pinto um tigre e uma onça acuados no Paraíso, com olhar instigado, observando o lado direito do quadro como se de lá viesse alguém em suas direções, dando a sensação que surgirá uma nova presença, que haverá uma invasão. Esta obra intitulada "Quem invade o Paraíso?" (fig. 4) propulsiona a temática e a narrativa da série seguinte, "Retratos Gigantes" (fig. 10 a 13), a primeira deste período de pesquisa, que apresenta personagens que irão invadir e perturbar os tranquilos paraísos. 


\section{3 - SÉRIE "RETRATOS GIGANTES"}

A série "Retratos Gigantes" traz de volta ao meu repertório o retrato da figura humana, que pratiquei assiduamente durante os meus estudos no Liceu de Artes e Ofícios de São Paulo. Isto aguçou e instigou minha criatividade para novas realidades pictóricas, retratando os indivíduos em suas características particulares, tal como o pintor deve ressignificar o mundo e a vida.

Roger de Piles afirmou: "Estou convencido de que cada pessoa em particular, tendo um espírito diferente, considera com uma visão diferente os fins a que se propõe, e que é possível alcançar os objetivos por meios diversos; e penso que cada um segue a inclinação de seu espírito (...)". ${ }^{11}$ Partindo desse pressuposto, estabelece três etapas distintas na composição de retratos, a saber, "o esboço, a pintura e o retoque". ${ }^{12}$ Essa terceira etapa, do retoque, seria para acrescentar ao retrato o que lhe falta e, principalmente, "para Ihe dar alma, fisionomia e caráter". ${ }^{13}$

O retrato me motiva e me leva a observar os detalhes da sua evolução histórica. É perceptível que no séc. XV as pessoas eram retratadas com um intuito de fidedignidade, com as suas rugas, dobras e cílios visíveis, aspectos fisionômicos caracterizados com perfeição. Piles sugere que, ao fim da composição de um retrato, deve-se colocar a tela ao lado do retratado, para que se "possa julgar definitivamente, através da comparação entre os dois, se nada falta para a perfeição absoluta de sua obra". ${ }^{14}$ Os retratos deste período representam desde os homens e seus ofícios, até as damas e seus cachorros. Os elementos e suas disposições que formam a composição conferiam status ao retratado. Entretanto, neles se percebe também um fundo neutro, simples,

\footnotetext{
11 PILES, 2006, p. 55.

12 Ibidem. 56.

${ }^{13}$ Idem, Ibidem. p. 57.

${ }^{14}$ Idem, Ibidem, p. 61.
} 
geralmente fundos verde-acinzentados, como nos retratos produzidos por Francisco José de Goya (1746-1828), Van Dyck (1599-1641) e Frans Hals (1580-1666) (figuras 5, 6 e 7), obras do acervo do MASP. As poses hieráticas de suas figuras históricas simbolizam o poder que exerciam em sua época. Só quando os retratados começam a ser colocados diante da paisagem é que surge um fundo mais elaborado, período em que aparecem os retratos de cenas.

Fig. 5
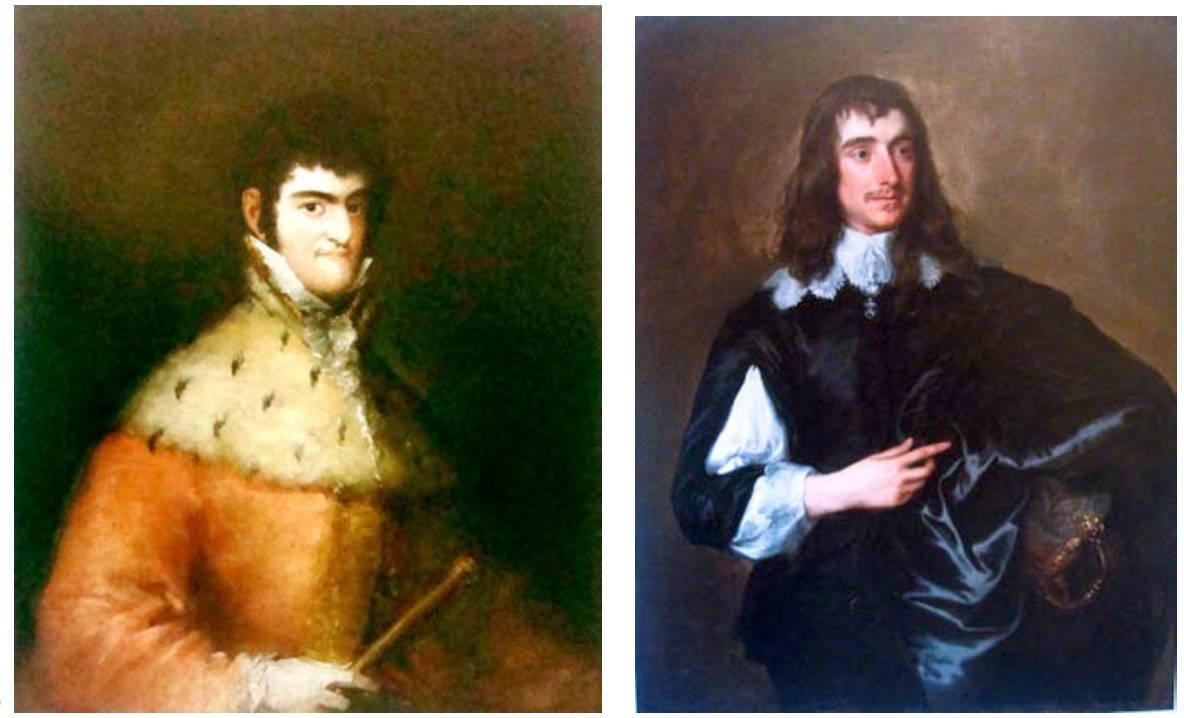

Fig. 6

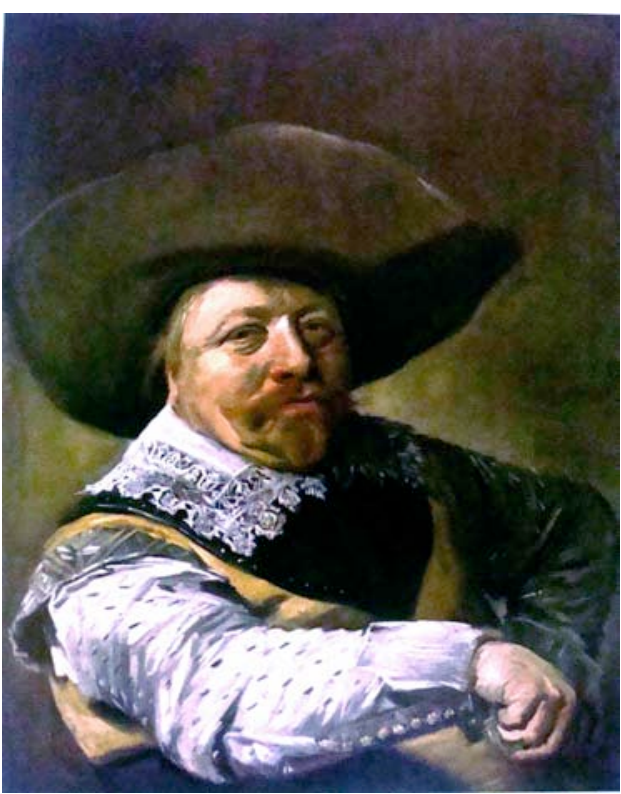

Fig. 5 - Francisco Goya - "Retrato de Fernando VII", 1808 - óleo sobre tela, 84,5×68,5 cm

Fig. 6 - Antonny Van Dyck - "Retrato desconhecido", 1640 - óleo sobre tela, 107x82 cm

Fig. 7 - Frans Hals - "Oficial sentado”, 1631 - óleo sobre tela, $82 \times 66 \mathrm{~cm}$ 
O gênero do retrato submete-se às características de cada estilo de época. No barroco, por exemplo, a mudança da luz em alguns pintores é focada no rosto do retratado, uma luz única, lateral, a 45 graus, que gera o claro-escuro. Segundo o crítico e historiador Arnold Hauser, na pintura barroca tudo o que é:

"sólido e estável começa a vacilar; a estabilidade expressa pelas horizontais e verticais, a idéia de equilíbrio e simetria, os princípios de enchimento da superfície e de ajustamento da pintura à linha da moldura são depreciados; um lado da composição é sempre mais enfatizado do que o outro; ao observador é repetidas vezes mostrado o aparentemente acidental, improvisado e efêmero, em vez dos aspectos 'puros' da face e do perfil." ${ }^{15}$

Assim, as novas conquistas formais da arte barroca estão presentes em retratos produzidos por Rembrandt (1606-1669), Caravaggio (1571-16101) (fig. 8), Johannes Vermeer (1632-1675) (fig. 9), Frans Hals e Francisco José de Goya. Tais pintores alcançaram em seus retratos uma intenção dramática.

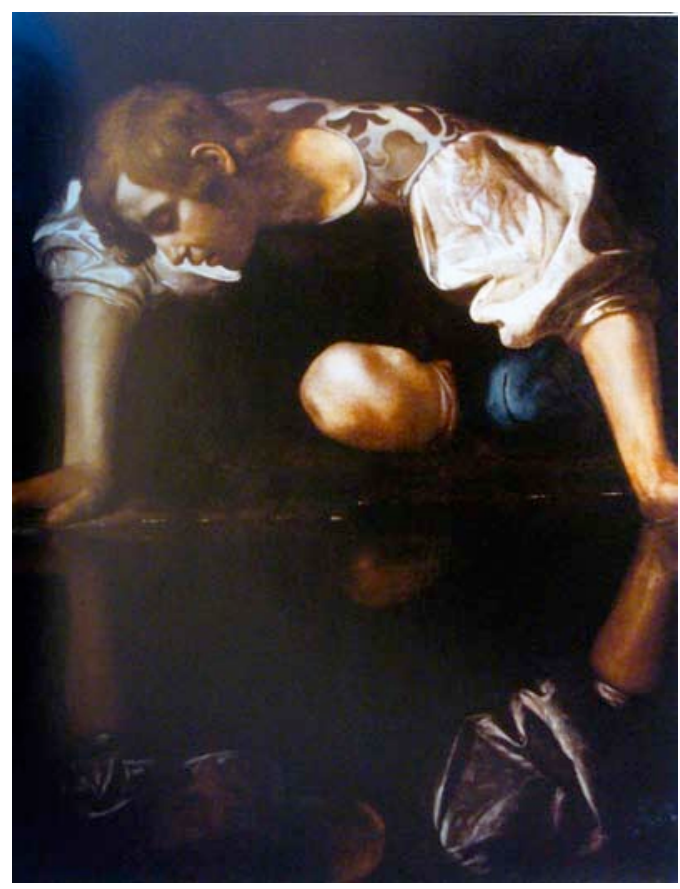

Fig. 8 - Caravaggio - "Narciso", 1596

Óleo sobre tela, $110 \times 92 \mathrm{~cm}$

Galleria Nazionale D’arte Ântica

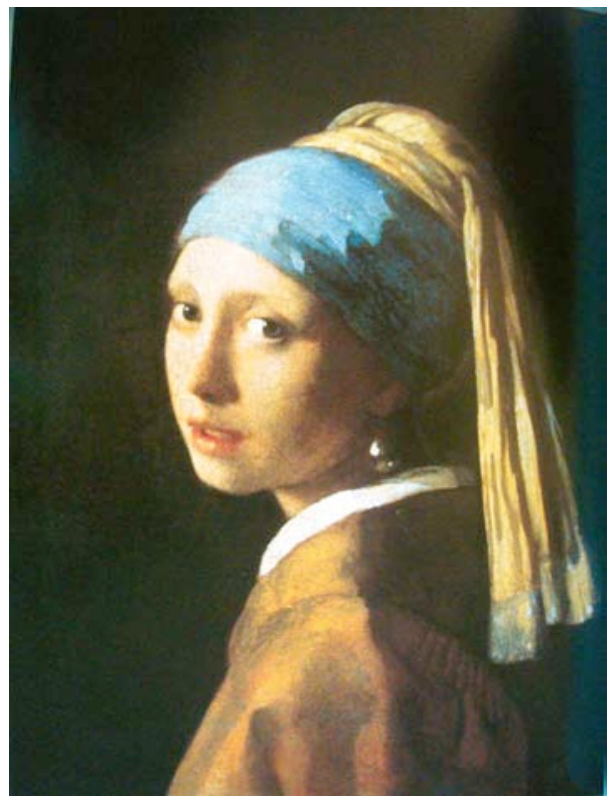

Fig.9 - Vermeer - "A moça do brinco de pérola”, 1665 - Óleo sobre tela, 46,5×40 Royal Pictura Gallery Mauritshuis

\footnotetext{
${ }^{15}$ HAUSER, Arnold. História social da arte e da literatura. São Paulo: Martins Fontes, 1995. p. 446-447.
} 
No caso de Goya, o escritor e crítico de arte francês Jori-Karl Huysmans, num estilo de escrita poética que cria uma analogia com a dramaticidade pictórica do pintor espanhol, comenta assim uma tela que representa uma tourada

No fundo do circo, cavalos se inquietam, e aqueles esmagados da paleta, os esfregaços de estopa, as manchas do polegar transformam-se numa multidão pululante, que se entusiasma, desafia, ameaça, emite urros ensurdecedores. Tudo é simplesmente soberbo. (...) Nunca se viu numa tela algazarra tão desenfreada; nunca uma paleta criou balbúrdia tão intensa. ${ }^{16}$

No caso de Van Gogh, Argan (1992), comentando a obra "Retrato do carteiro Roulin", de 1888, aponta

(...) evidencia-se que Van Gogh aprendeu com os impressionistas tudo o que diz respeito às influências recíprocas entre as cores, mas tais relações não o interessam como correspondências visuais, e sim como relações de força (atração, tensão, repulsão) no interior do quadro. Em virtude dessas relações e contrastes de forças, a imagem tende a se deformar (...); pelas aproximações estridentes das cores, pelo desenvolvimento descontínuo dos contornos, pelo ritmo cerrado das pinceladas, que transformam o quadro numa composição de signos animados por uma vitalidade febril e convulsa. Em Van Gogh, a substância pictórica adquire autonomia, não há propriamente representação: aqui a pintura é. ${ }^{17}$

Como pudemos perceber, ao longo da história da pintura, o retrato se liberta da necessidade de verossimilhança e começa ter outras configurações: torna-se esfumaçado, como na pintura impressionista, ou mesmo geométrico, sob a ótica do cubismo. No Brasil, temos os casos de Flavio de Carvalho (18991973) e Wesley Duke Lee (1931-2010), que fizeram retratos que transcendem a

\footnotetext{
${ }^{16}$ HUYSMANS, Jori-Karl. Goya e Turner. A cor moderna. In LICHTENSTEIN, J. A Pintura. V. 9: O desenho e a cor. São Paulo: Ed. 34, 2006. p. 118.

${ }^{17}$ ARGAN, 1992, p. 111.
} 
imagem figurativa, tratando muito mais da pintura em si do que da personagem figurada.

Flávio de Carvalho, segundo Rui Moreira Leite (1998), em telas como Retrato de Silva Neves (aquarela, 1928, col. Roberto A. Neves, São Paulo) e seu Auto-Retrato (óleo, 1928, col. particular, São Paulo) que "são as primeiras nas quais se liberta das convenções de representação herdadas do seu período de estudos na Inglaterra." 18

De acordo com Cacilda Teixeira da Costa, em Wesley Duke Lee percebemos que "no desenrolar de seu trabalho, em diferentes expressões da imagem, (o artista) modifica os sistemas tradicionais de representação, vivenciando intensamente cada meio disponível, da têmpera medieval ao computador". ${ }^{19}$

Assim como a transformação da luz e na pintura, com a fotografia surge a libertação total de um tratamento fidedigno em relação às cores. Já que a fotografia por natureza é fidedigna, a pintura de retratos se torna a impressão do que se sente sobre a figura e não sua mera representação objeto pintado. De acordo com Argan, "os serviços prestados por artistas, como retratos, paisagens e ilustrações passaram a ser feitos por fotógrafos." ${ }^{20}$ A pintura por sua vez torna-se uma atividade ainda mais elitizada. Diante desse impasse, oriundo da nova tecnologia industrial,

(...) as soluções que se apresentam são duas: 1) evita-se o problema sustentando que a arte é atividade espiritual que não pode ser substituída por um meio mecânico (é a tese de Baudelaire e, posteriormente, dos simbolistas e correntes afins); 2) reconhece-se que o problema existe e é um problema de visão, que só pode ser resolvido definindo-se claramente a distinção entre os tipos e as funções da imagem pictórica e da

${ }^{18}$ LEITE, Rui Moreira. Modernismo e Vanguarda: o caso Flávio de Carvalho. Revista Estudos Avançados. v. 12, n. 33, São Paulo, mai. /ago.1998. p. 236.

${ }^{19}$ COSTA, Cacilda Teixeira da. Retrospectiva Wesley Duke Lee. São Paulo: Masp; Rio de Janeiro: Centro Cultural Banco do Brasil, 1992/1993. p. 11.

${ }^{20}$ ARGAN, 1992, p. 78. 
imagem fotográfica (é a tese dos realistas e dos impressionistas). ${ }^{21}$

Com isso, abre-se mais espaço para a expressão individual do artista e para pesquisas mais profundas acerca da linguagem da pintura. $O$ objeto, como índice, é reinterpretado, transformando-se em outro índice, que pode remeter ao retratado, à própria pintura (metalinguagem) ou a outras idéias.

Se o objetivo for o retrato, a pintura do rosto de um indivíduo não é apenas um registro físico desse ser: deve ir além, apreender o seu caráter, sua expressão corporal e atentar para os detalhes, para que a imagem pictórica não só se pareça com a pessoa, mas represente também sua personalidade. Um traço, um aspecto ou uma cor fazem a diferença na semelhança do retratado. Conhecer o retratado é muito mais importante para o sucesso do retrato, do que ser fiel a uma imagem primeiramente captada numa fotografia, porque muitas vezes a pessoa não é fotogênica e a foto torna-se apenas um instante congelado deste indivíduo. Um intuito mais legítimo do retrato seria o de registrar o seu jeito, os feitios, o temperamento do retratado, pelos quais os outros o conhecem e o reconhecem. Da mesma forma como acreditavam os índios sobre a fotografia, o retrato tem que "roubar a alma da pessoa". "Já em 1310, Pietro d'Abano (1250-1315), filósofo, considerado o primeiro historiador da arte, recomendava que o retrato deveria expressar a aparência e a psicologia, em suma, a alma do retratado". ${ }^{22}$

Tentando retratar de modo que transcenda a mera transmissão da imagem da pessoa, na série "Retratos gigantes" não busco uma semelhança fiel às personagens. Formo composições com menos elementos, que tendem a ser divertidas, visando também que se perceba a constituição física da pintura, como a cor, a textura e as camadas de velaturas.

\footnotetext{
${ }^{21}$ Ibidem, p. 79.

${ }^{22}$ COELHO, Teixeira. "Olhar e ser visto". Denis Donizetti e Bruza Molino. São Paulo: Comunique, 2008. p.54.
} 
De acordo com o sociólogo Richard Sennett, "a intimidade com o ofício faz com que o pensamento possibilite outros caminhos, que o artista não pense mais na feitura, mas em algo inovador, mudando o conteúdo. Porque parece que isso é o que a arte busca: inovação." ${ }^{23}$ A busca pelo domínio da técnica faz com que eu não tenha, posteriormente, uma preocupação racional com a pincelada, e me detenha em outras questões, como o contraste criado entre as partes, tanto na luminosidade, como no contraste cromático; a composição de cores; o uso de volumes ou sua negação; a leitura da obra como um todo, como uma composição orgânica; as sobreposições; as colagens de elementos; dentre outras questões que surgem durante o desenvolvimento da pintura.

Com essa busca pelo domínio da técnica, o artista vai desvelando o conceito do seu trabalho. O artista só é capaz de se envolver emocional e intelectualmente com seu trabalho quando consegue se concentrar por longos períodos sobre seu ofício. A capacidade de concentração física segue regras próprias, baseadas na maneira como as pessoas aprendem a praticar, a repetir e a aprender com a repetição. A concentração tem uma lógica interna gerada pelo próprio indivíduo.

Os artesãos, artífices, pintores, artistas podem ser tão apaixonados por seus ofícios que estão entregues ao pensamento da produção o tempo todo, como se não pudessem se desligar: pensam e refletem constantemente sobre sua arte. O fazer artístico toma conta do artista de tal forma que é impossível não enxergar o mundo com um olhar que transforma um objeto cotidiano em arte. No caso do artista contemporâneo, começa a existir arte, como dimensão estética, em todos os momentos rotineiros da vida. No seu entorno, por causa do seu modo de ver, o artista plástico transforma tudo em imagem pictórica.

Ainda segundo Sennett:

(...) a diferença se dará na originalidade que conseguirá em cada produção. Entramos então no conceito de originalidade, que

\footnotetext{
${ }^{23}$ SENNETT, Richard. "O Artífice"; tradução de Clovis Marques. - Rio de Janeiro: Record, 2009, p.72.
} 
remonta a uma palavra grega, poiésis, que era utilizada por Platão e outros para designar 'algo onde antes nada havia'. A originalidade é um marcador do tempo; denota o súbito surgimento de alguma coisa onde antes não havia nada e pelo fato de algo de repente passar a existir, suscita em nós sentimentos de admiração e espanto. ${ }^{24}$

Na pintura contemporânea podemos superar os conceitos básicos mais dogmáticos, as regras, mas só com o exercício individual o artista consegue desenvolver sua originalidade, seu modo próprio de expressão.

No modernismo o retrato se libertou da necessidade de refletir fielmente o retratado, trazendo novas possibilidades de abordagem. Tornou-se uma representação pictórica que exige criação, seja de cunho intelectual, conceitual, espiritual e psicológica. Como afirmou Baudelaire, "Quanto mais a matéria é, em aparência, concreta e sólida, mais o trabalho da imaginação é sutil e laborioso. Um retrato! Que há de mais simples e mais complexo, de mais evidente e mais profundo?" ${ }^{25}$ O poeta simbolista francês considera ainda que, para o pintor, a "obediência" ao aspecto do retratado deve ser equivalente à intuição criadora. Assim é que hoje pinto o retratado, enquanto exercito o meu modo de expressão pictórica.

Diferentemente do realismo, pretendo pintar impregnando a obra do meu olhar, que interfere na existência das coisas, projetando-lhe minha visão particular dele. Interessa-me aqui outra forma de representação. Um dos poucos aspectos em que me remeto ao retrato clássico é quanto à atemporalidade, localizando este retrato numa relação tempo-espaço indefinível.

Nesta série "Retratos Gigantes" ("O Paraíso") as cenas, antes habitadas somente pelos animais, são agora tomadas pela presença de pessoas, de uma forma descontraída, sensação essa gerada pela feitura desproporcional dos elementos figurativos. Na obra "Celsinho e seu animal de estimação em viagem

\footnotetext{
${ }^{24}$ Idem, ibidem, p.192.

${ }^{25}$ BAUDELAIRE, 2006, p. 128
} 
de férias pelo Golfo do México" (fig. 10), a personagem, de modo irreal, é pintada muito maior do que o animal, e colocada em uma situação anedótica. Utilizo minha memória afetiva para criar ironia, retratando-o ao levar o animal na coleira para passear, como se fosse um animal de estimação.

O artista é sensível ao seu entorno. Assim, para realizar esta série, fui motivada pelos meus amigos do meio artístico, os quais se tornaram protagonistas da cena. Sinto-me sempre provocada a reinterpretar pessoas, animais e lugares, principalmente pela relação afetiva com eles.

Nesta série, retrato pessoas com diversas atividades ligadas às artes visuais, tais como críticos, galeristas, divulgadores e apreciadores em geral, pessoas que trabalham na pós-produção de arte, que não são autores, mas como colaboradores e observadores finais.

Vale acrescentar que nas obras "Bom dia" e "O anjo da Natasha" (Fig. 11 e 12) já se pode notar uma diferença na utilização das cores, agora mais amenas, trazendo calma às paisagens. Essa opção cromática terá continuidade nas obras seguintes. 


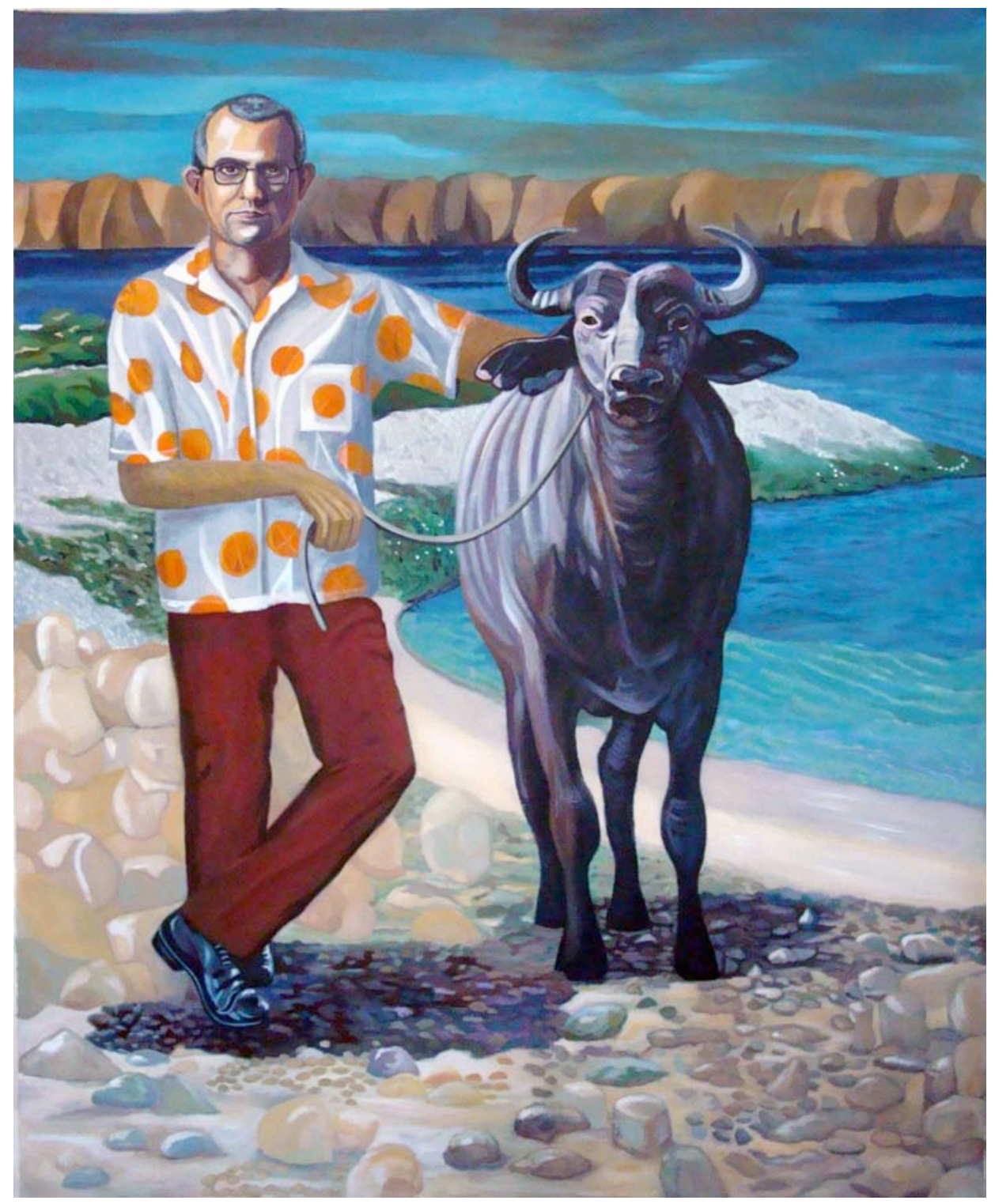

Fig. 10 - Fernanda Eva - "Celsinho e seu animal de estimação em viagem de férias pelo golfo do México", 2009

Acrílica sobre tela, $210 \times 170 \mathrm{~cm}$

Coleção Particular 


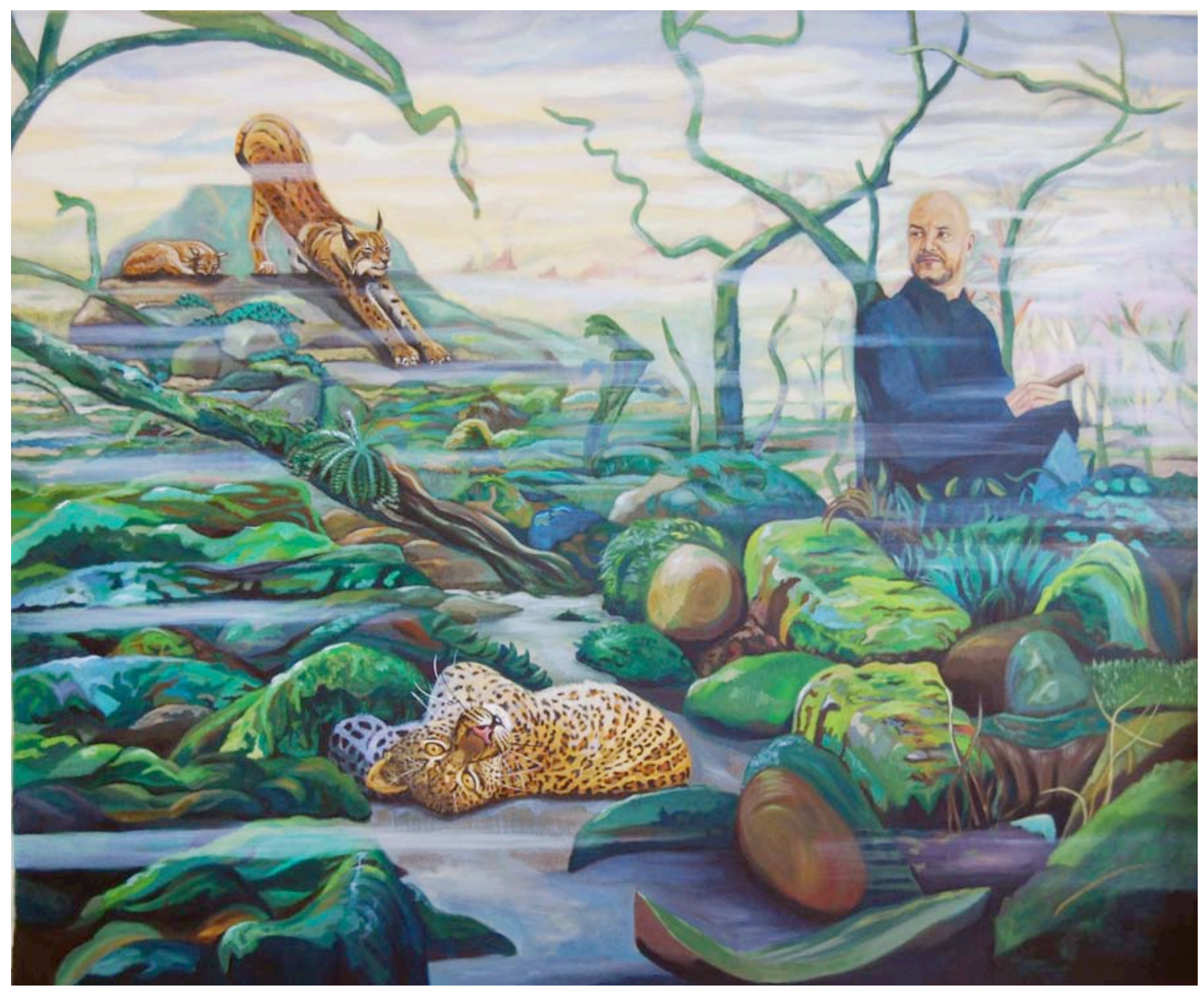

Fig. 11 - Fernanda Eva - "Bom dia", 2009

Acrílica sobre tela, $170 \times 210 \mathrm{~cm}$

Coleção Particular 


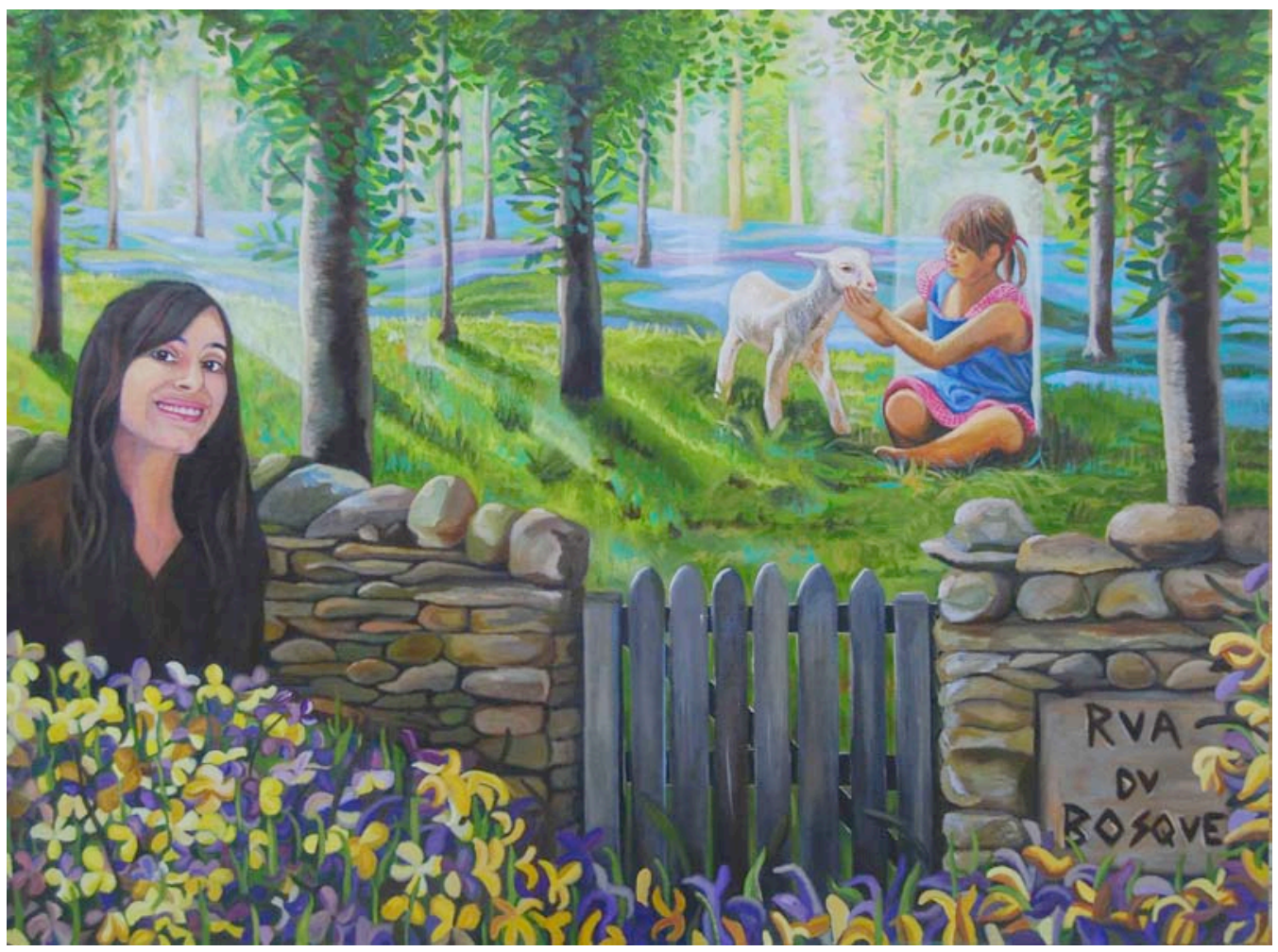

Fig. 12 - Fernanda Eva - "O Anjo da Natasha", 2009

Acrílica sobre tela, $140 \times 180 \mathrm{~cm}$

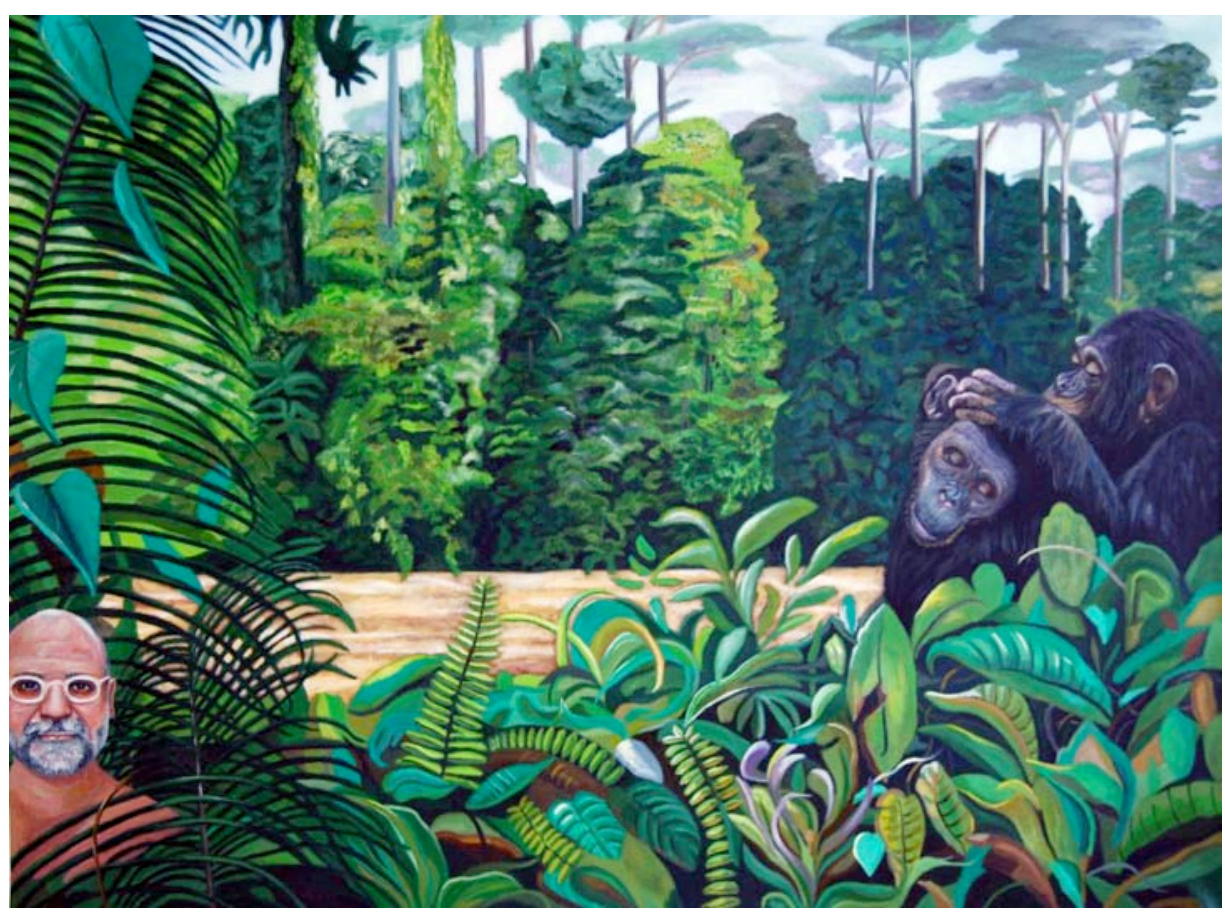

Fig. 13 - Fernanda Eva - "Sem titulo, ainda", 2009

Acrílica sobre tela, $140 \times 180 \mathrm{~cm}$ 


\section{4 - LUCIAN FREUD}

Outro artista de referência para minha produção é o pintor alemão, naturalizado britânico, Lucian Freud (1922), que figura no contexto do Neo-expressionismo na Inglaterra. Freud tem

(...) a capacidade estarrecedora de revelar a carne, as entranhas e o espírito do homem. Tem a prodigiosa sensibilidade de introjetar as qualidades, as condições psíquicas e físicas e o estado de alma de seus personagens e de explorar a essência fenomenológica da pintura. ${ }^{26}$

Meu interesse por Freud foi motivado por ele caracterizar seus elementos figurativos de modo que se apresentem psicologicamente fortes e nítidos. Seus retratos trazem essa expressividade psíquica, em que as personagens são identificadas por possuírem várias partes bem definidas. Mas a beleza de sua obra se dá não pelo que pode haver de realismo, mas pela atmosfera criada, transmitindo sensações do psicológico do retratado.

Esse processo dos retratos psicológicos de animais, presente na minha série "Paisagens", foi aplicado também nas figuras humanas, nas séries "Retratos Gigantes" e "Paraísos".

Mostrando pessoas frágeis em suas pinturas, no momento em que parecem totalmente vulneráveis, tanto pela fisionomia, como pelo fato de aparecerem nuas, os retratos de Lucian Freud remetem-nos a uma intimidade profunda. As personagens, colocadas em posições inusitadas, em poltronas ou camas, suscitam a análise no divã. Provocam no espectador uma sensação por vezes de desolamento, timidez, de desprendimento e abandono.

\footnotetext{
${ }^{26}$ LEIRNER, Sheila. Arte e seu tempo. São Paulo: Ed. Perspectiva, 1991. p. 381
} 


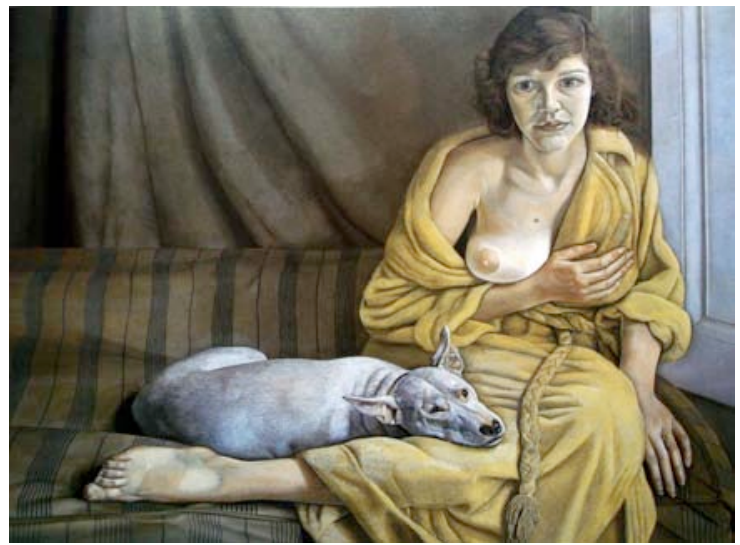

Fig.14 - Lucian Freud - "Menina com cachorro branco" - Óleo sobre tela, 76,2×101,6 cm Trustees of the Tate Gallery

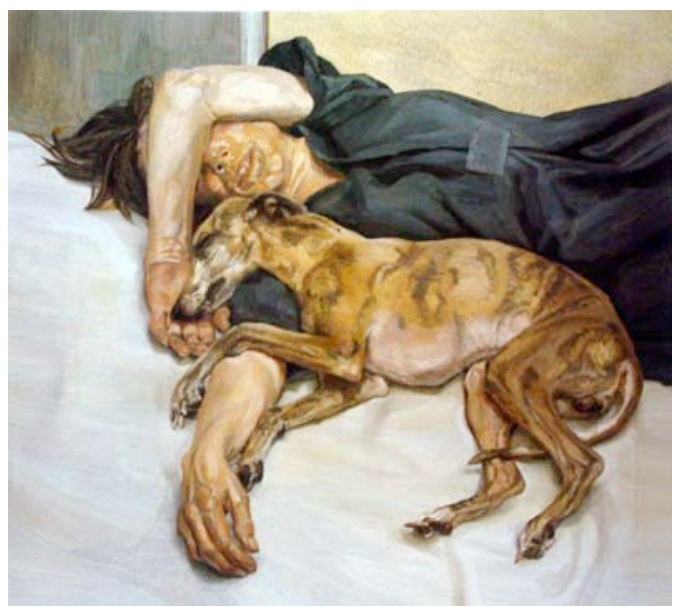

Fig. 15 - Lucian Freud - "Retrato duplo" 1985/86 - óleo sobre tela, 78,8×88,9 cm Coleção Particular

Freud também retrata animais, entretanto somente animais domesticados. Em algumas de suas obras retrata a pessoa junto com o animal e, através do título, confere a mesma relevância pictórica às pessoas e aos cachorros retratados, como nas obras Menina com cachorro Branco (Fig.14) e Retrato Duplo (fig. 15). Nesta fase mais antiga de sua obra, as figuras ainda são retratadas vestidas, apenas mais tarde elas aparecerão nuas.

Tecnicamente a beleza de sua obra não se dá pela fidelidade às tonalidades cromáticas dos corpos, mas pela variedade de cores alcançada e pela riqueza na pincelada espessa, e pelo gesto não uniforme. Segundo Leirner:

Por meio de cores desagradáveis, pinceladas e formas truculentas, Freud é mais elementar, mais orgânico, mais pictórico na gênese das distorções que cria. Essa correspondência direta, sensual e repulsiva, entre a humanidade palpável e a tactibilidade da pintura, é o que contém a poesia genuína e a ressonância psicológica essencial de sua obra.

A exemplo deste artista busco em minhas obras impregnar de cores as figuras, de modo a investigar seus traços de autenticidade.

\footnotetext{
${ }^{27}$ Ibidem, p. 182.
} 
Lucian Freud evoca em seus trabalhos a memória, a sensualidade e envolvimento emotivo, assuntos para ele autobiográficos. Acredito que todo trabalho de criação artística é um tanto biográfico, porque mesmo que não tenha consciência, o artista é motivado por situações, objetos, por elementos concretos de sua vivência.

Neste sentido, retrato as pessoas "não precisamente pelo que elas parecem, não exatamente pelo que elas são, mas como elas deveriam ser." ${ }^{28}$ No meu modo de vê-las e interpretá-las, como na série "animais da arte" (fig. 19 até fig. 25) procuro criar imagens metafóricas. São retratos de amigos, a exemplo de Lucian Freud, que pintou um bom número de amigos artistas, por exemplo, o pintor Frank Auerbach (fig. 16).

Assim como em Freud, na pintura contemporânea as personagens são retratadas com um realismo cru, mostrando suas falhas, sem disfarces, como aconteciam nos primeiros retratos ou mesmo no seu auto-retrato "Reflexão" (fig.17) .

Todo objeto de arte encontra o seu encanto em ter um segredo, um mistério a ser desvendado, seja na sua forma, na sua estrutura, no seu conteúdo, ou na sua idéia. O desvendar das metáforas de cada trabalho, ação do espectador, gera novos significados que são assimilados à obra.

${ }^{28}$ LUCIAN FREUD paintings. Londres: thames \& Hudson, 1988, p. 54 


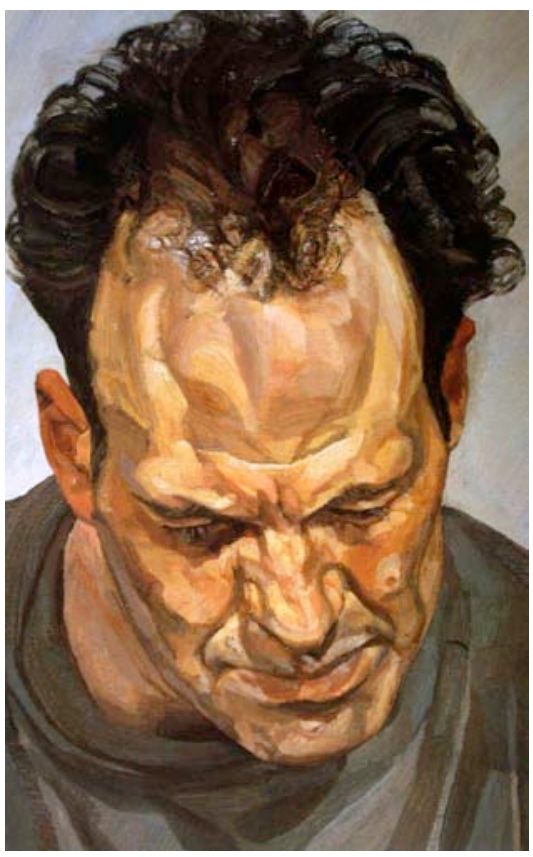

Fig 16 - Lucian Freud - Frank Auerbach - 1975/76

Óleo sobre tela $-40 \times 26,5 \mathrm{~cm}$

Coleção Particular

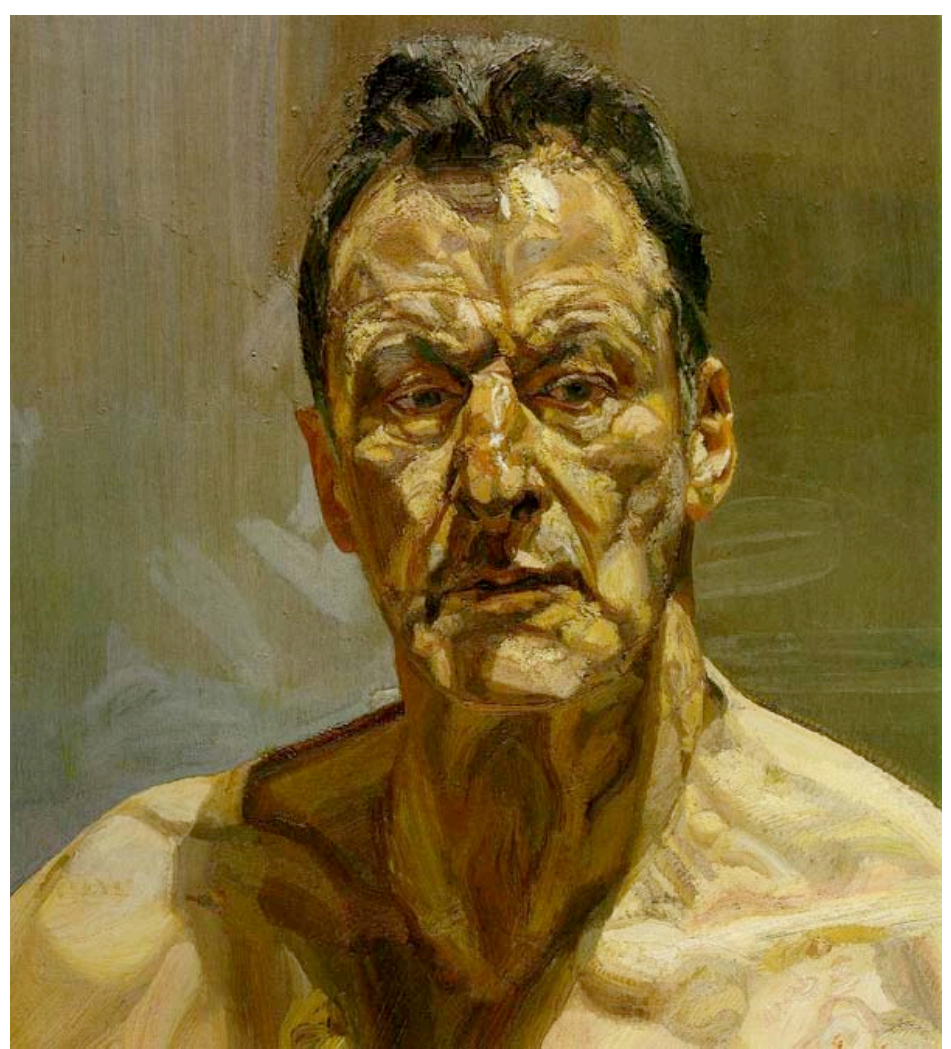

Fig.17 Lucian Freud - Reflexão (auto-retrato) - 1985

. Óleo sobre tela - 56,2×51,2cm

Coleção Particular 


\section{5 - SÉRIE "ANIMAIS DA ARTE"}

$\mathrm{Na}$ segunda série produzida nesta pesquisa, continuam sendo retratadas pessoas escolhidos por afinidade afetiva. Mas agora também participam, em quase todas as cenas, colegas de ofício, pessoas que também produzem obras artísticas, seus próprios "Paraísos". São pintores, desenhistas, fotógrafos e um assessor de imprensa. Entretanto, buscando a ironia por meio dos títulos, a ênfase das obras não se dá no retratado, mas ao animal que sempre acompanha essas personagens. Quero criar um ruído na recepção da obra, questionando quem de fato é o animal, quem é efetivamente o protagonista da cena.

Nesses trabalhos as cores se amenizam, desta vez com um fundo chapado num tom de cinza, resultado da observação dos trabalhos da fotógrafa alemã Loretta Lux, que retrata pessoas com certa distorção, em tons pastéis. Um exemplo está nas fotografias abaixo (Fig. 18). O formato das telas diminui, possuindo agora em média $100 \times 80 \mathrm{~cm}$ e recebem uma moldura, conferindo uma atmosfera clássica aos retratos, inusitada, em contraste com as figuras em companhia de animais, numa atmosfera coloquial e informal.
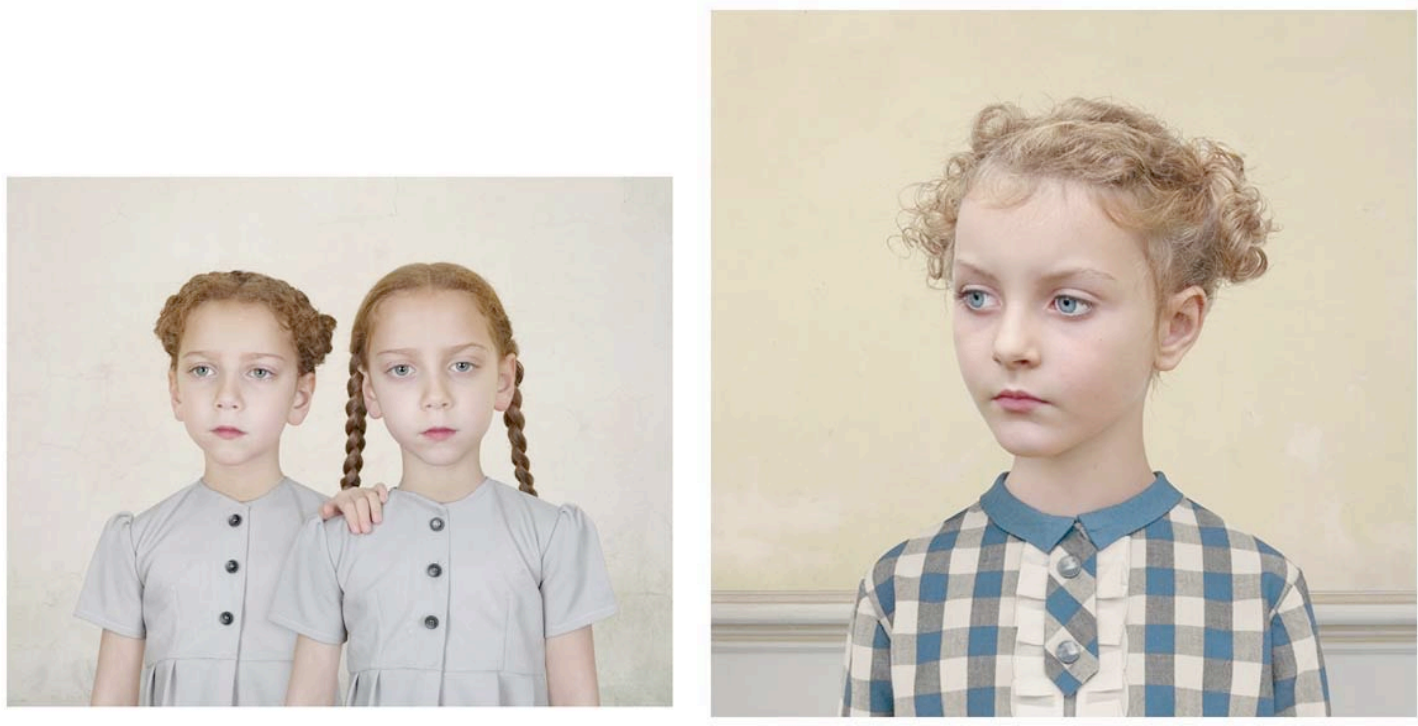

Fig. 18 - Fotografias Loretta Lux 
É uma prática comum na contemporaneidade os pintores se apropriarem de obras canônicas da história da arte e produzirem releituras. Pensando nisso me apropriei da obra da própria artista por mim retratada. Na tela "Animais em festa" (fig. 19) pinto a artista Flavia Junqueira com balões, em que a pose de perfil é uma referência aos seus próprios auto-retratos em fotografia. Acrescento uma onça no seu colo, animal do meu repertório, criando uma imagem lúdica e ilusória ao colocá-la sentada nos balões que segura.

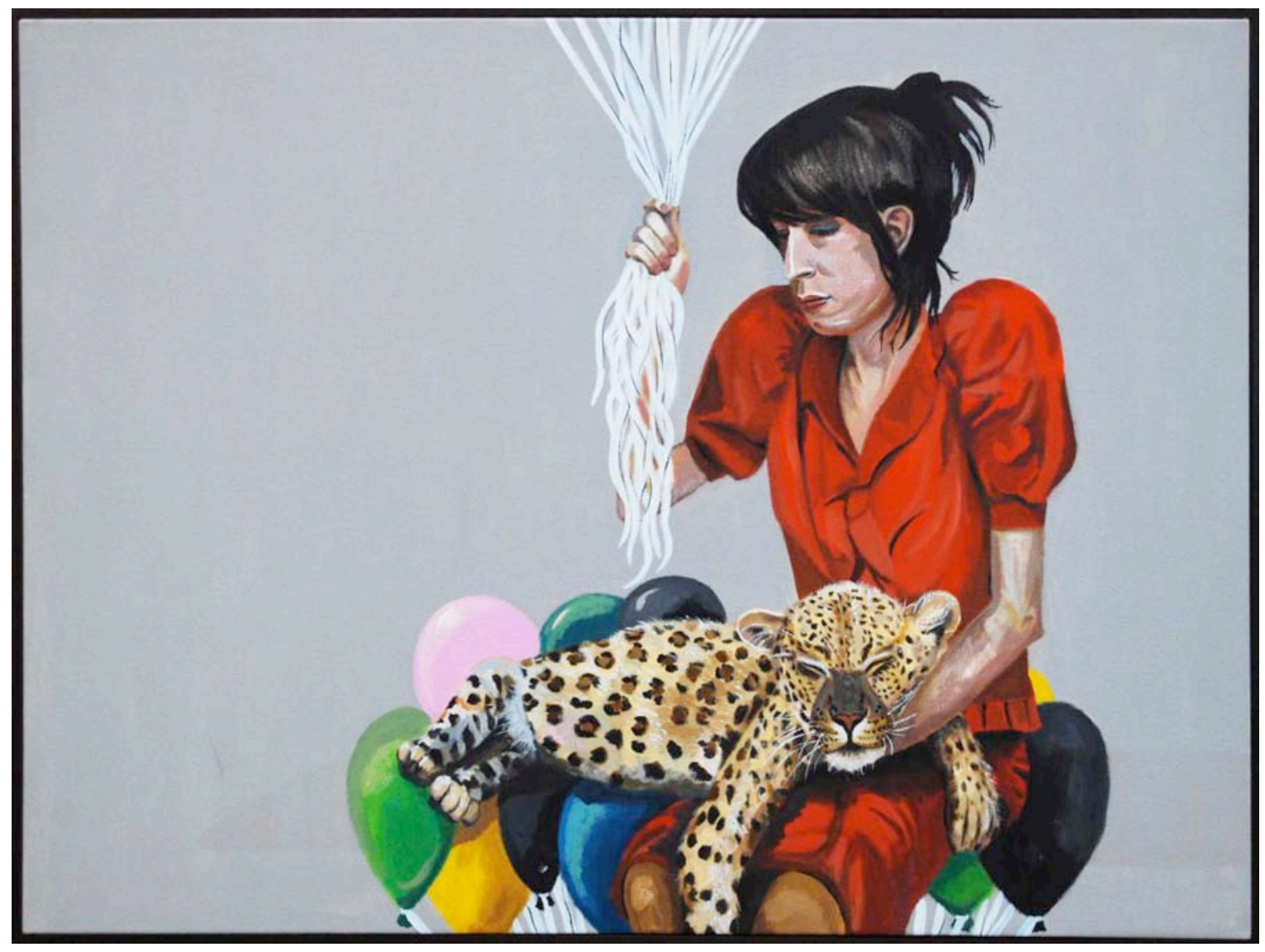

Fig. 19 - Fernanda Eva - "Animais em festa”, 2010

Acrílica sobre tela, $104 \times 97 \mathrm{~cm}$

Em algumas de minhas pinturas me aproprio dos motivos que estes artistas utilizam para compor suas obras, como no retrato "O piolho" (Fig. 20). O pintor Mauricio Adinolfi atualmente está pintando uma série retratando macacos. Para efeito de ironia, na cena retrato-o com uma macaca the tirando piolhos o que só se completa com o título. 


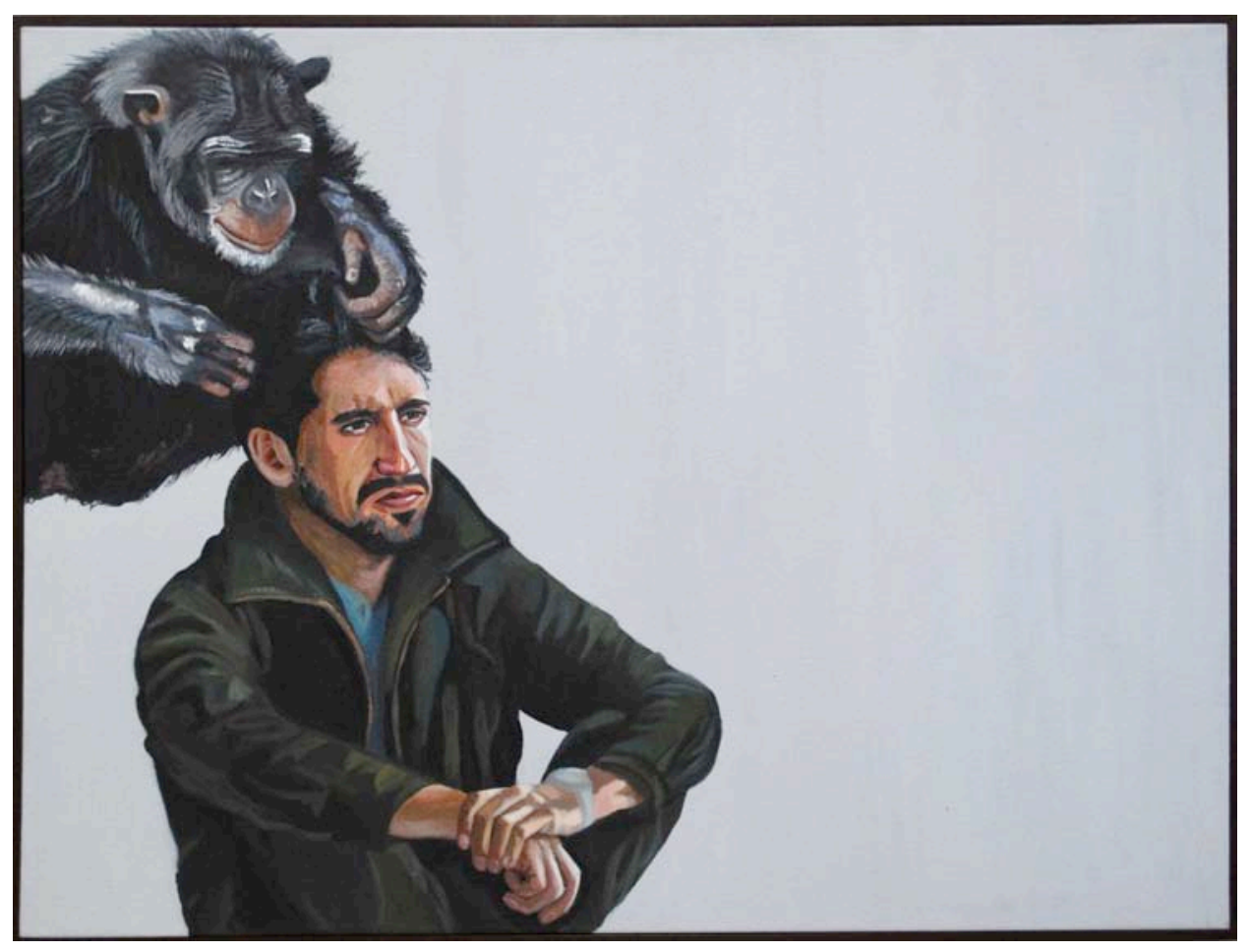

Fig. 20 - Fernanda Eva - "O piolho”, 2010

Acrílica sobre tela, $86 \times 113 \mathrm{~cm}$

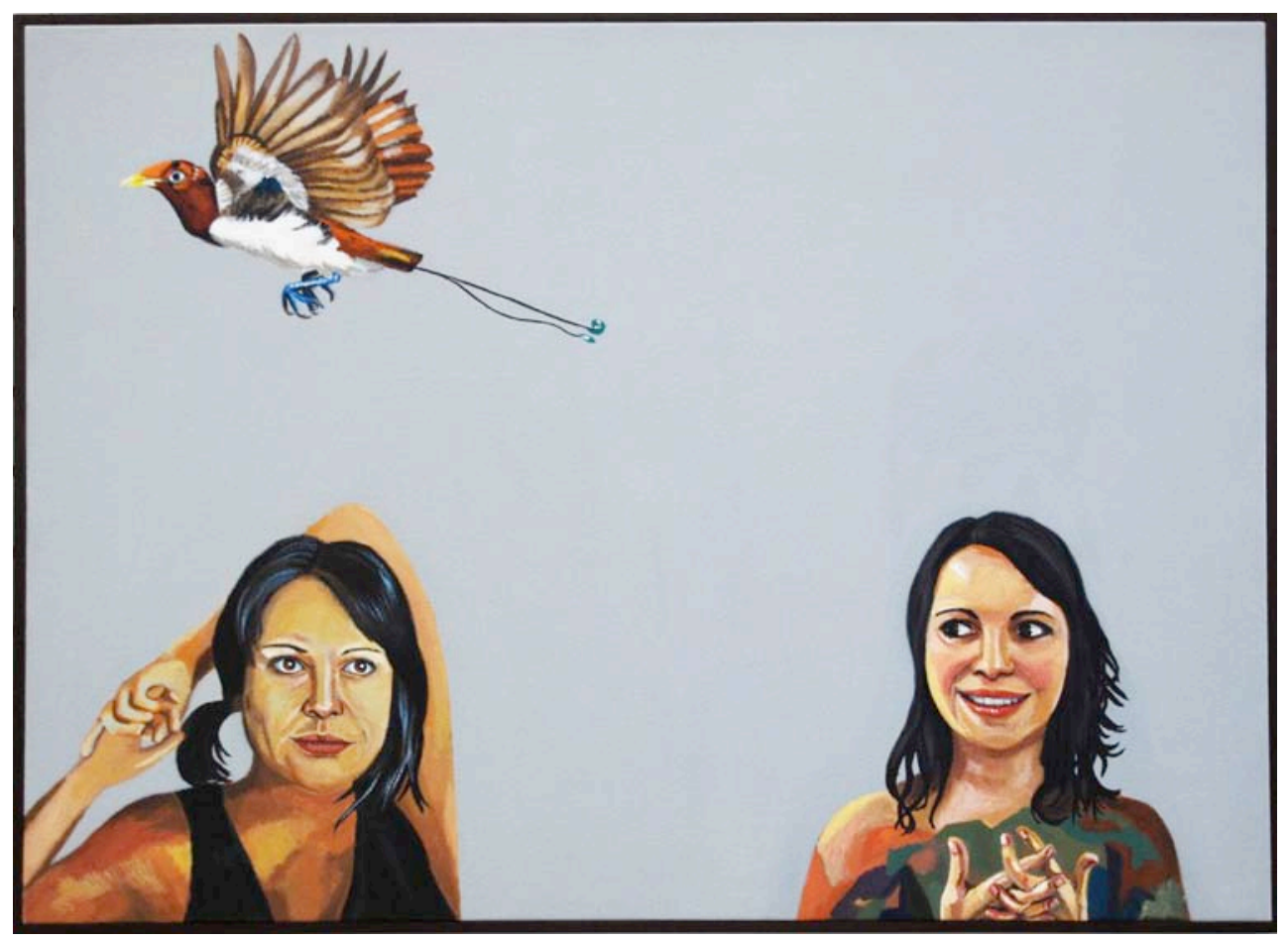

Fig. 21 - Fernanda Eva - "Patinhas", 2010

Acrílica sobre tela, $87 \times 120 \mathrm{~cm}$ 


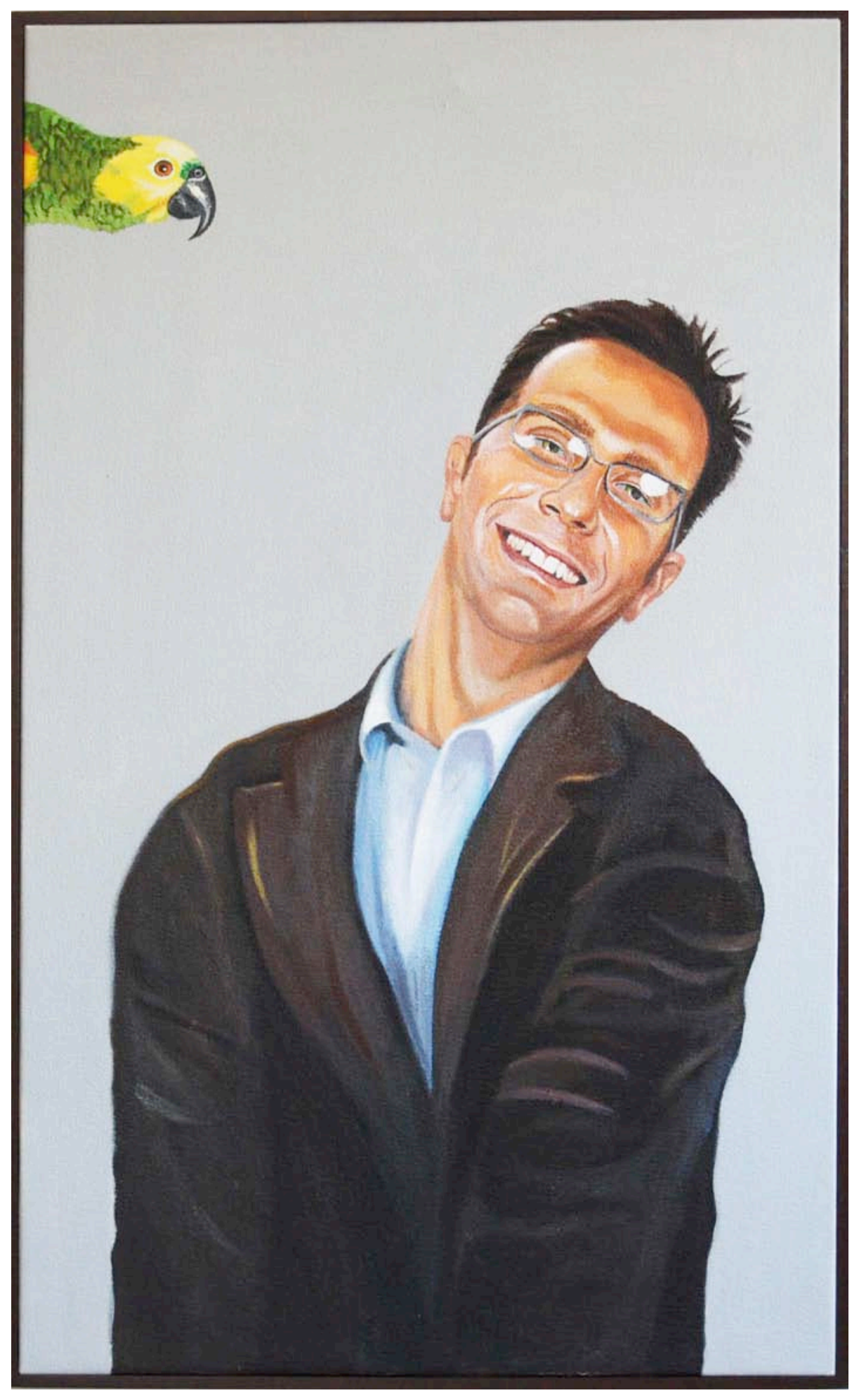

Fig. 22 - Fernanda Eva - "Papagaio verdadeiro e seu assessor", 2009 Acrílica sobre tela, $104 \times 64 \mathrm{~cm}$ 


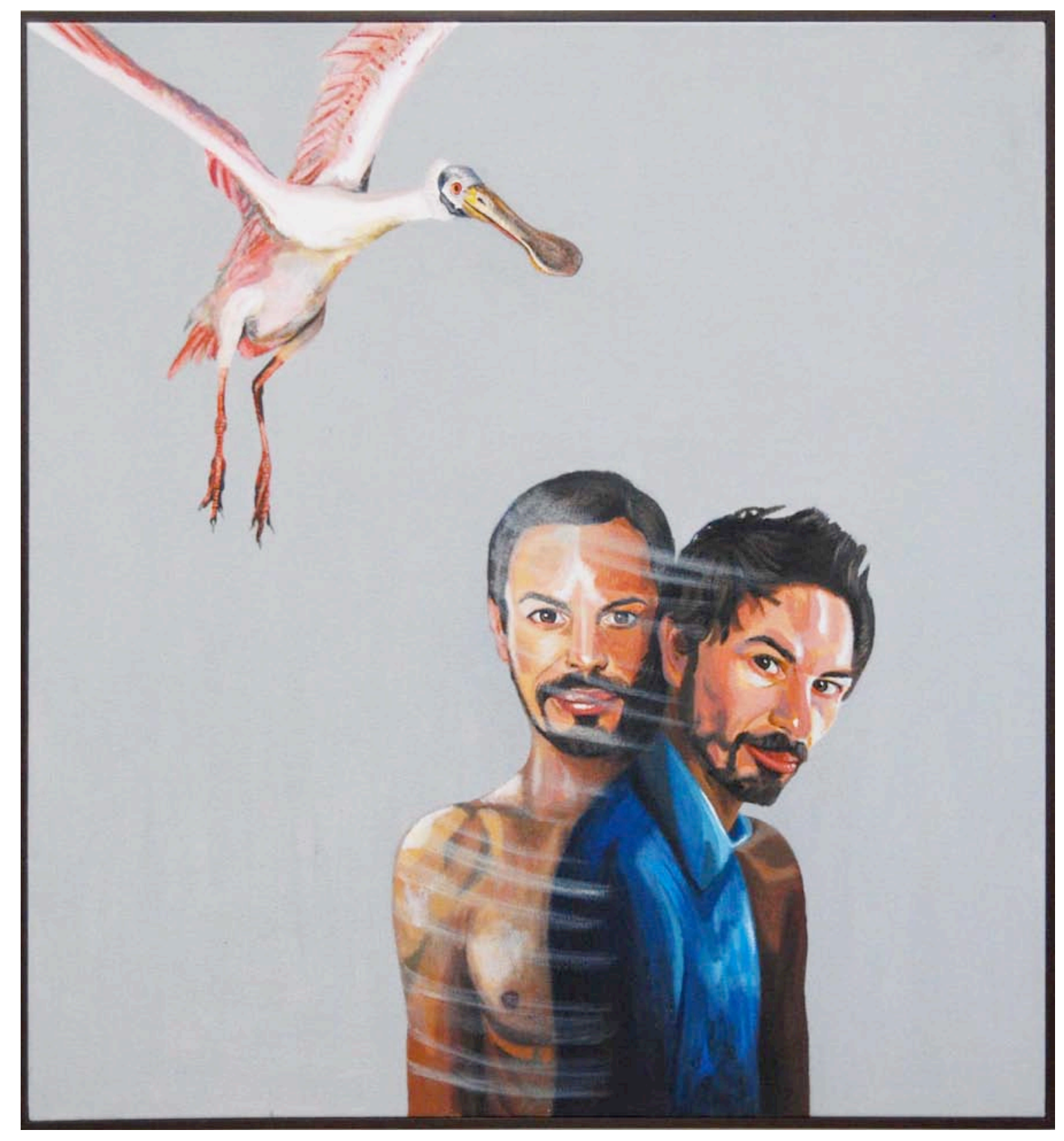

Fig. 23 - Fernanda Eva - "Eco em meu corpo", 2009

Acrílica sobre tela, $107 \times 100 \mathrm{~cm}$

Na tela "Eco em meu corpo" (Fig. 23) dialogo ludicamente com o conceito de Merleau-Ponty, das coisas causando efeito no corpo do artista. Mas coloco-o mesmo causando o efeito, com o movimento, o retratado aparece vestido. Coloco o artista Nino em duas posições tentando dar a idéia de transformação, metamorfose dele mesmo. $O$ eco do próprio corpo sendo retratado na tela, 
utilizando um novo elemento em minha pintura: a fundição de mais de uma imagem para formar o corpo. Coloco duas imagens da mesma pessoa tentando gerar a idéia de movimento, como nos trabalhos de Duchamp, um movimento suspenso. Neste caso, intento propor a seguinte questão: o colhereiro acima dele é apenas um espectador da cena ou pode ele se transformar também em uma ave?

Inspiro-me na idéia de Marcel Duchamp "a pintura é a crítica do movimento e que o movimento é a crítica da pintura. A análise, a decomposição e o reverso da velocidade são reflexões sobre a imagem". ${ }^{29}$

O artista Duda Rosa (fig.25) é por sua vez retratado com um porco no colo. O porco é rosa e o nosso retratado é palmeirense e tem o sobrenome Rosa: o jogo de ironia entre palavra e imagem se completa, já que os torcedores deste time de futebol são vulgarmente chamados de porcos.

Nas obras desta série "Animais da arte" utilizo de elementos hilariantes tentando conectar a obra com o homem através da indeterminação, da distorção, da contradição e satirizarão. Esta série é uma alavanca, uma ponte, para a realização de auto-retratos na série "Paraísos".

${ }^{29}$ PAZ, Octavio/ Marcel Duchamp, ou, O castelo da pureza - São Paulo: Perspectiva, 2008, p.8. 


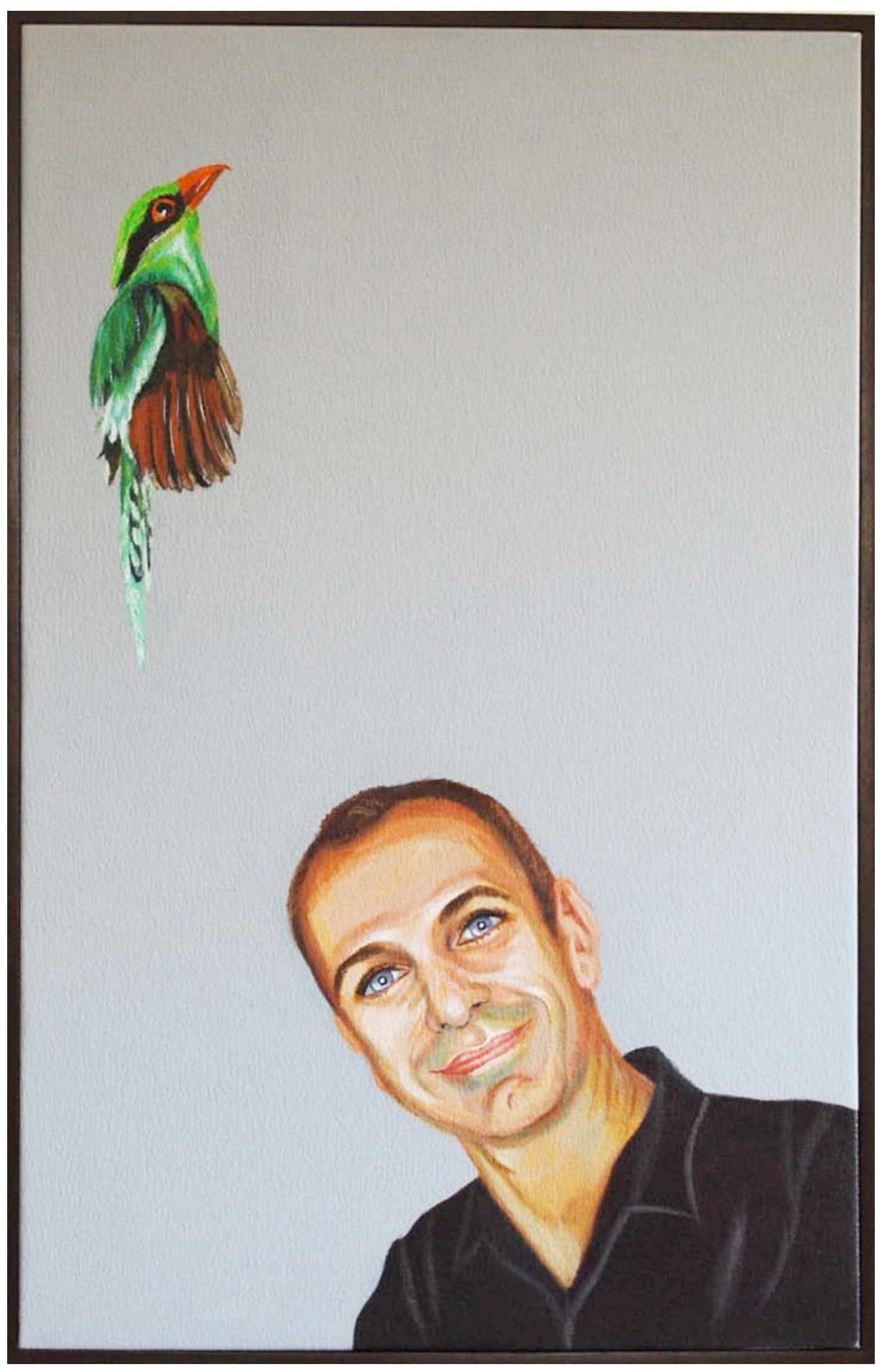

Fig. 24 - Fernanda Eva - "Pega-verde de olho azul", 2010

Acrílica sobre tela, $89 \times 56 \mathrm{~cm}$ 


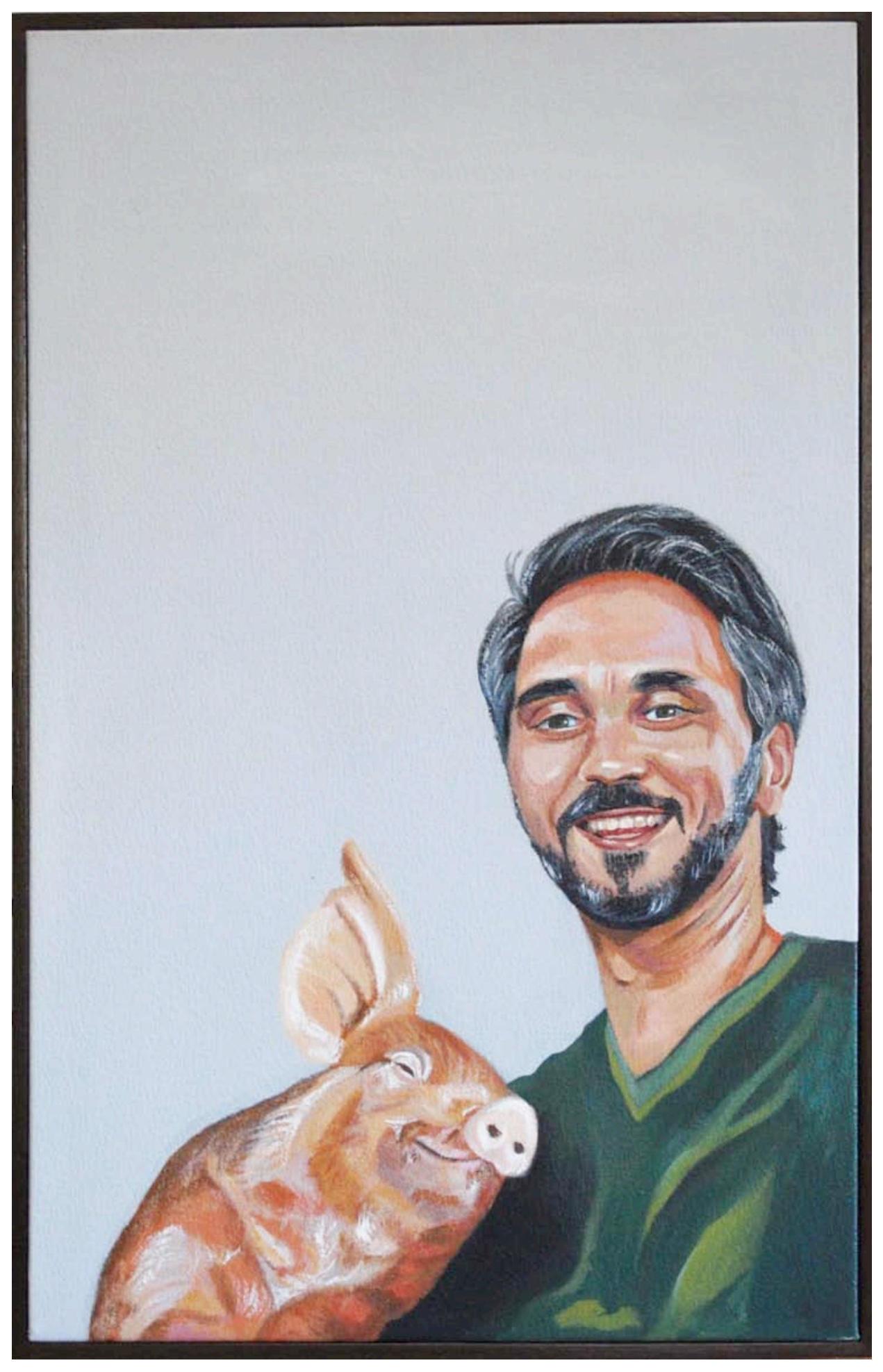

Fig. 25 - Fernanda Eva - "Animais Rosa", 2010 Acrílica sobre tela, $89 \times 56 \mathrm{~cm}$ 


\section{6 - A FOTOGRAFIA}

Em um primeiro instante, a fotografia aparece na minha produção como referência para a execução das pinturas, trata-se de fotos dos lugares de preservação que visitei e registrei. Essas fotografias não foram feitas para serem copiadas fielmente, mas sim como suporte, para a partir delas serem criadas novas composições.

Ensaiando-se o tema "Paraísos" surge a série de fotografias "Paraísos Fantasmagóricos" que compreende 30 imagens. Vemos aqui fotos (fig.26 a 30) para cuja execução foi necessário preparação de cenário, iluminação, efeito de fumaça, etc. para se alcançar os resultados esperados.

Nesta produção são retratados novamente apenas os animais em seus "Paraísos". Entretanto Ihes é atribuído um clima novo de mistério. Um ar fantasmagórico habita essas florestas e matas povoadas de animais estranhos, ora de porcelana, ora de madeira, da minha coleção de animais, muito pequenos, mas que ao serem fotografados em close parecem grandes e criam um estranhamento na imagem. Este aspecto de bruma será também buscado na realização de várias pinturas subsequentes.

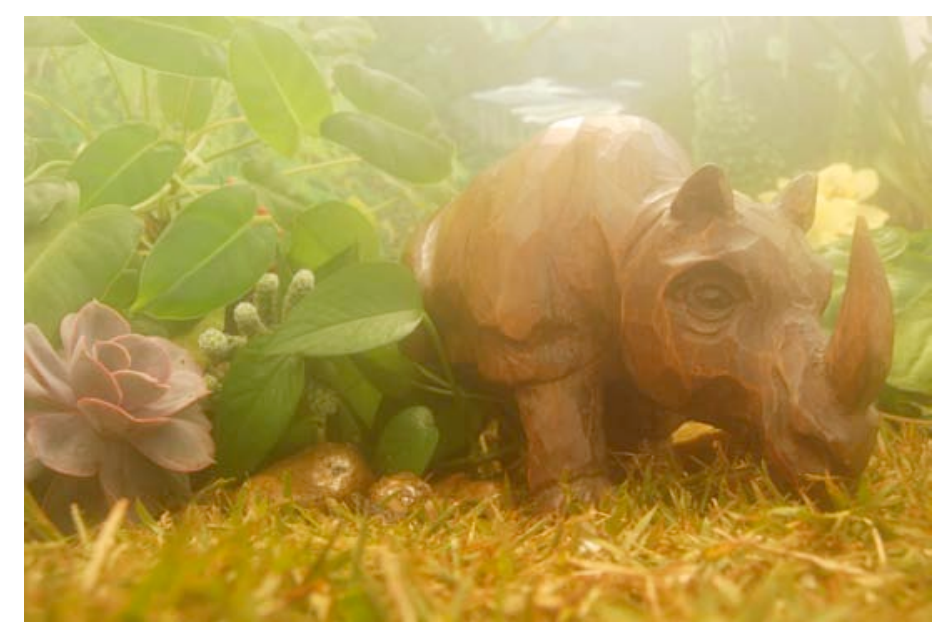

Fig. 26 - Fernanda Eva - Sem título, 2009

Fotografia 


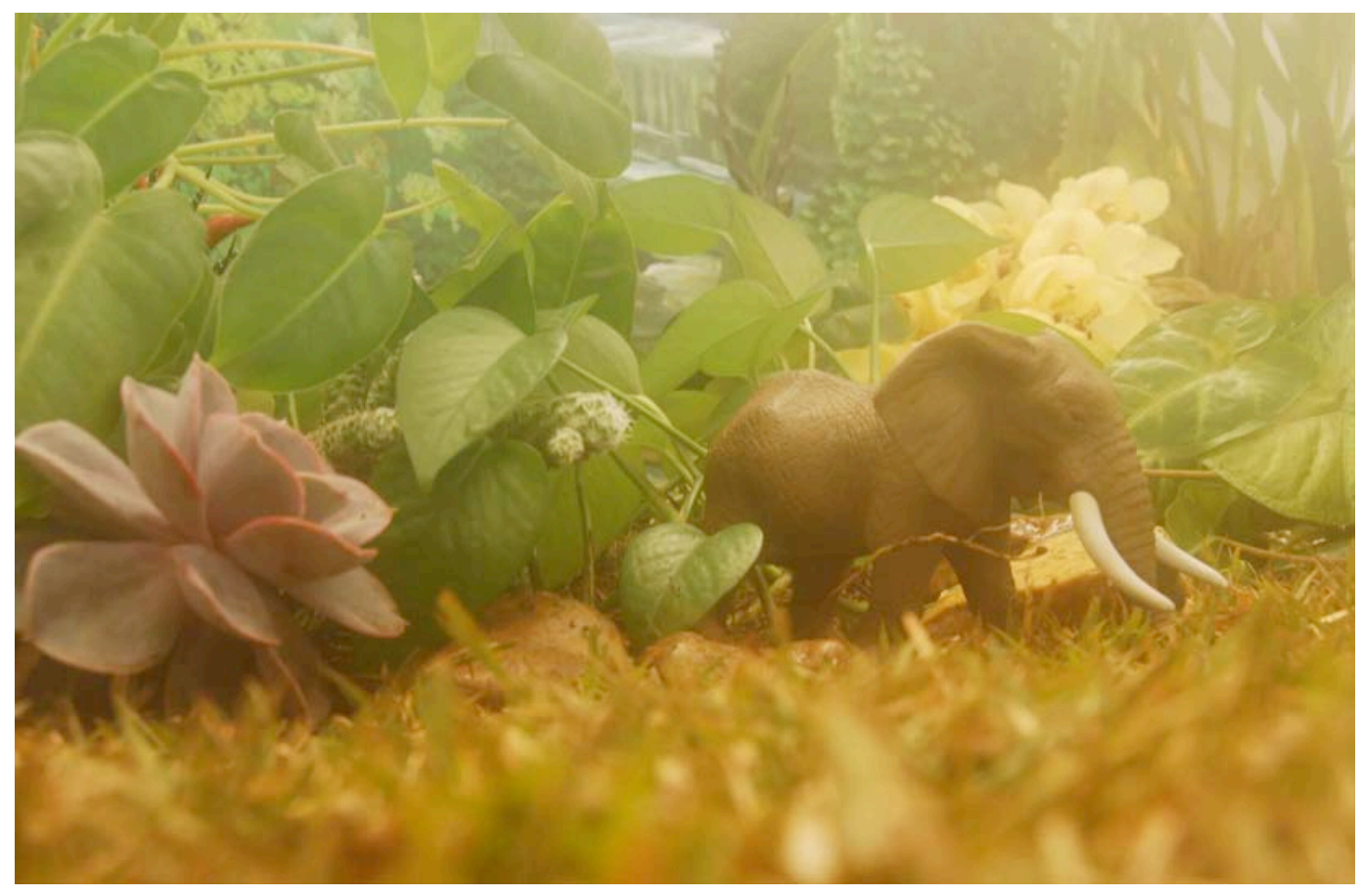

Fig. 27 - Fernanda Eva - Sem título, 2009

Fotografia

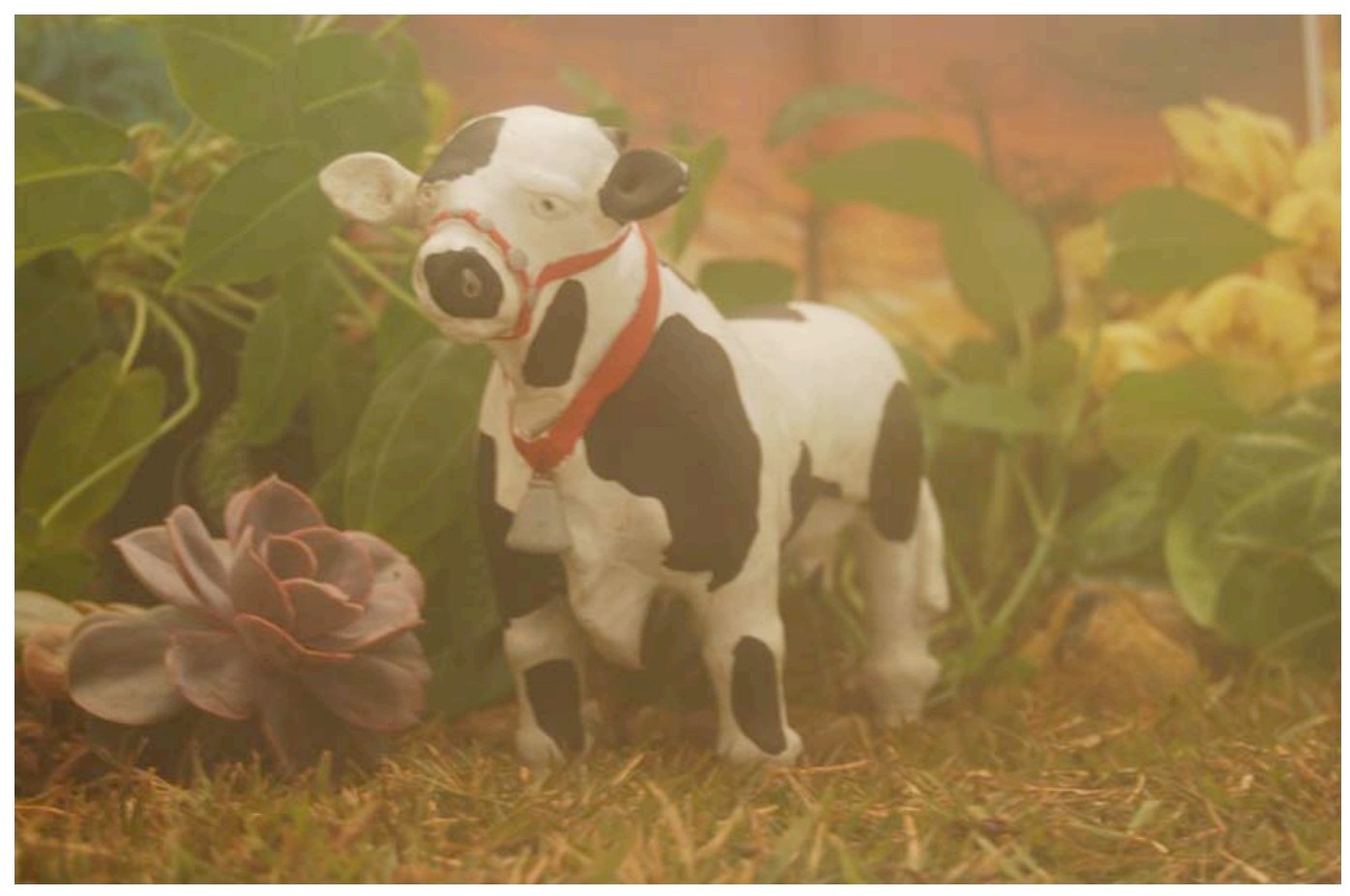

Fig. 28 - Fernanda Eva - Sem título, 2009 Fotografia 


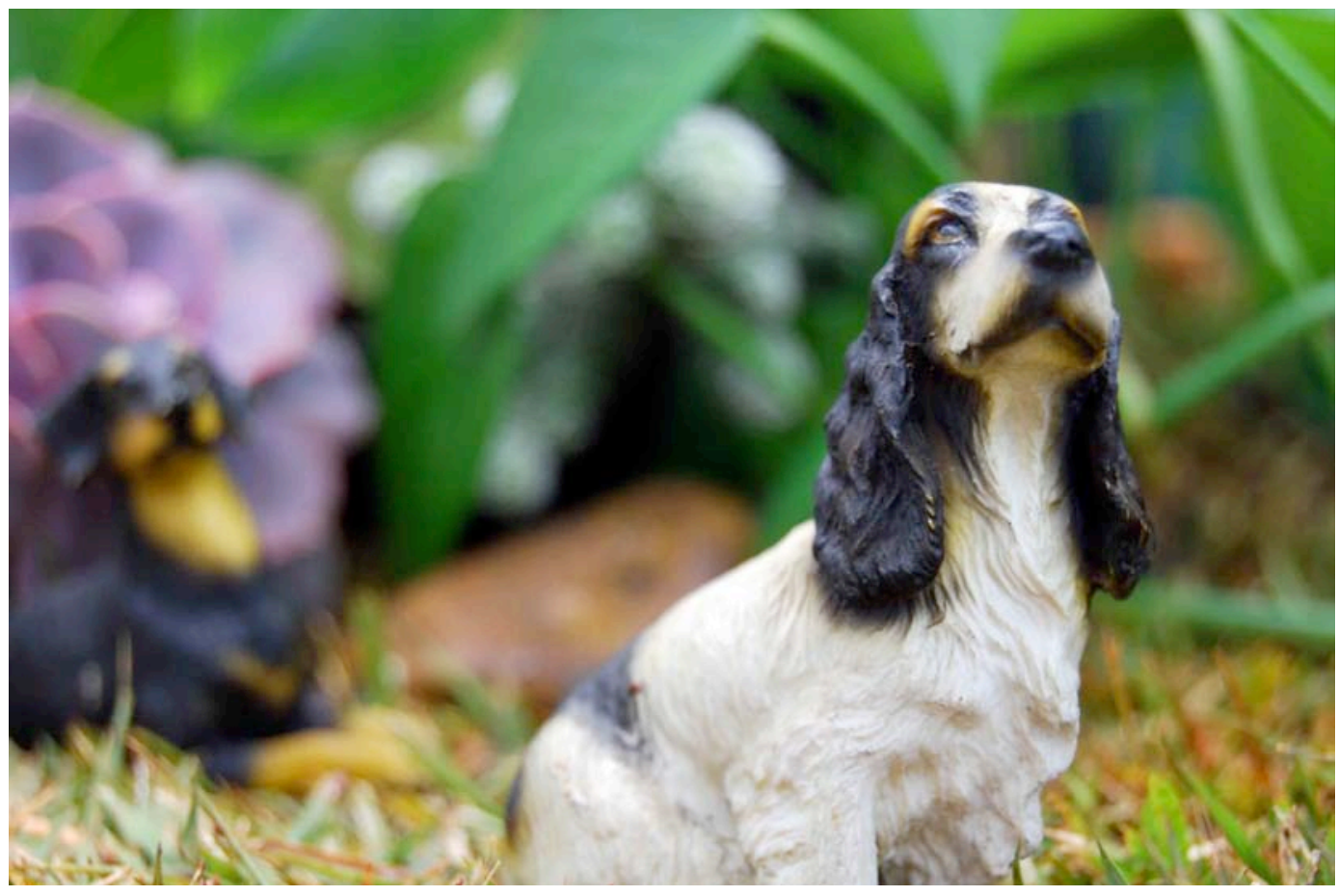

Fig. 29 - Fernanda Eva - Sem título, 2009 Fotografia

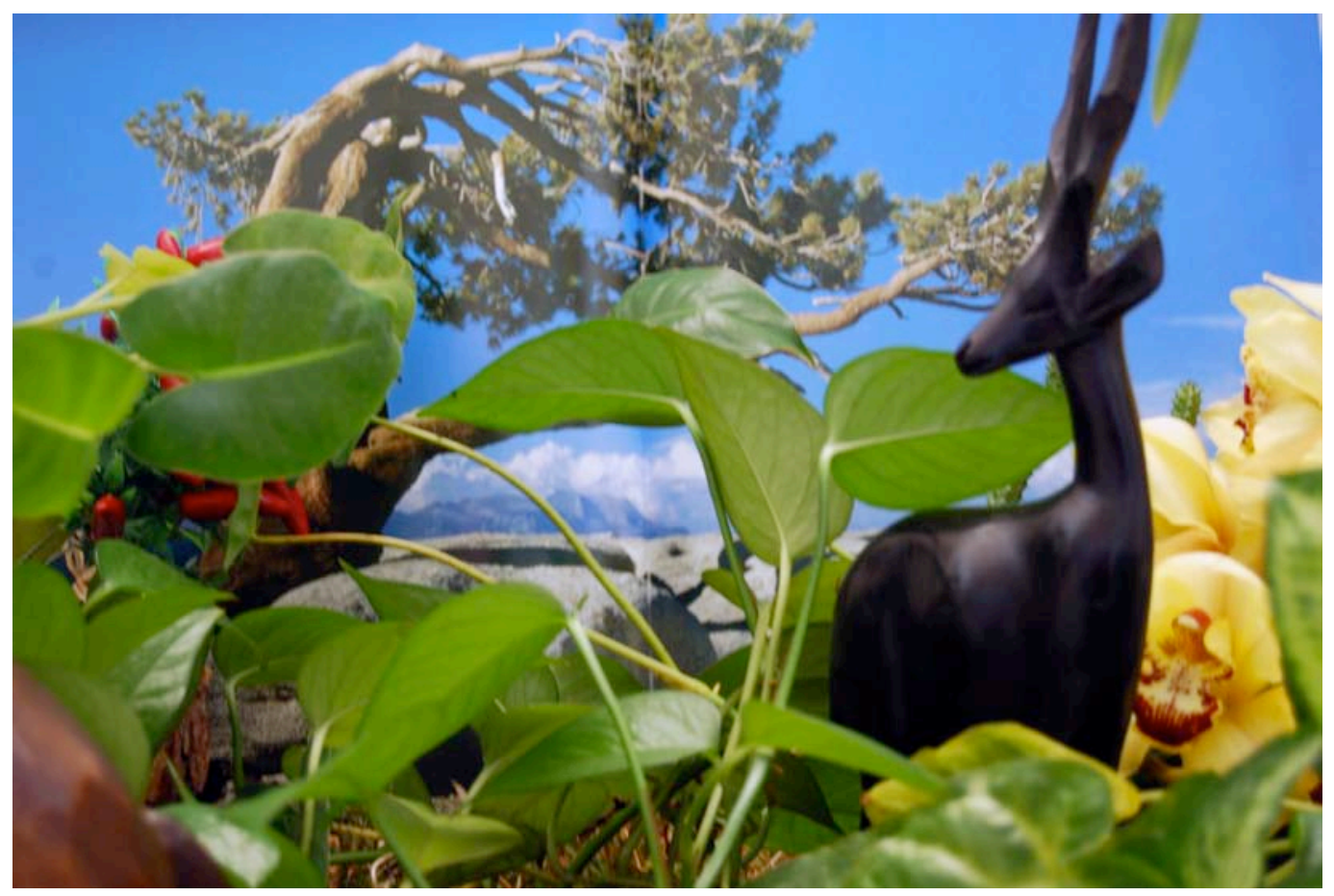

Fig. 30 - Fernanda Eva - Sem título, 2009

Fotografia 


\section{7 - CONSTRUÇÃO DA POÉTICA DOS "PARAÍSOS"}

A série "Paraísos" surge como um desdobramento das séries anteriores e como consequência das minhas composições face à observação das obras de outros artistas. Aqui, dou continuidade aos temas paisagem e retrato, mas mesclando as três formas de abordagem do tema paraíso.

A primeira abordagem da série refere-se ao imaginário bíblico, ao mitológico Jardim do Éden, onde habitavam Adão e Eva, na tradição hebraica.

O catálogo do Pavilhão dos Estados Unidos, organizado pelo The New Museum of Contemporary Art de New York, para a 41ㄹ Bienal de Veneza em 1984, registra uma exposição baseada nas obras "O Paraíso Perdido" (1667) e "Paraíso Reconquistado", do poeta inglês John Milton (1608-1674). É a história da queda de Lúcifer e a sequência trata da vinda de Cristo à Terra para reconquistar o que Adão teria perdido.

O escritor conta a história da queda do homem e sua redenção, uma luta entre o bem e o mal expressa através de uma rede de contrastes: o céu e o inferno, luz e trevas, amor e ódio, humildade e orgulho, criação e destruição.

Nas artes visuais, os pintores da paisagem norte-americana de meados e finais do século XIX abordavam ideais espirituais, retratando a vastidão, o mistério, a grandeza e variedade da paisagem norte-americana. A natureza foi de acordo com o pensamento de alguns, não só o exercício das emoções, mas um mentor filosófico que ensinou ao homem tanto o terror deste destino mortal, quanto à promessa de realização humana e da salvação final.

Assim, encontramos o termo "Paraíso" como Paraíso Terrestre, como definição de local da primitiva habitação do homem na tradição das religiões hebraicas. Segundo o livro do Gênesis, Deus criou Adão e Eva e lhes deu o Jardim do Éden, onde poderiam viver e comer todas as frutas, menos as da árvore do conhecimento do que é bom e do que é mal. Ao desobedecer esta 
ordem e comer o fruto proibido, Adão e Eva passam a conhecer o bem e o mal, nascendo assim entre os homens o pecado e a vergonha. Por isso são expulsos do Paraíso.

Tentar encontrar a felicidade e a harmonia, perdidas após a expulsão, é mote central para muitos artistas, principalmente na arte européia.

Numa série recente de meus trabalhos projeto cenas, em que a Eva se redime do pecado original, e traz os habitantes de volta ao Paraíso, apresentado agora como um local de magia e fantasia. Ainda na mitologia cristã, há a versão do Paraíso como a morada dos justos e dos bons, após a morte. Jan Brueghel, o Jovem (1568-1625), pintor flamenco, expressa-o com maestria na obra "Paraíso" (1620) (fig. 31), onde podemos observar as araras-azuis sul-americanas.

"A Divina Comédia" de Dante Alighieri (1265-1321) trata do modo católico, judaico-cristão e medieval de entender o mundo, através de uma viagem que o poeta faz aos estágios do mundo post mortem. Guiado pela alma do poeta latino Virgílio, Dante tem a revelação da "máquina do mundo". O poema é dividido em 3 partes, Inferno, Purgatório e Paraíso. Na terceira e última parte, o Paraíso, o poeta, guiado por Beatriz, sua amada ao céu da vida eterna. O Paraíso, num plano simbólico, representa o difícil encontro do homem com o criador, o que se dá apenas por interferência de Beatriz.

Segundo seu tradutor brasileiro, Cristiano Martins (1976), a Divina Comédia encerra uma forma “(...) a um tempo profunda e simples, velada e translúcida, objetiva e mágica, partícipe da terra e do céu, em sua poesia que desce ao coração dos homens e das coisas para aí surpreender os derradeiros, escondidos e sempre renovados mistérios da vida". ${ }^{30}$

Como artista plástica o que me interessa e desejo enfatizar é a vontade de representar o paraíso como um lugar para se estar feliz.

\footnotetext{
${ }^{30}$ MARTINS, Cristiano. A vida atribulada de Dante Aligheri. In: A Divina Comédia. São Paulo: Ed. Itatiaia / Ed. da Universidade de São Paulo, 1976. p. 81
} 


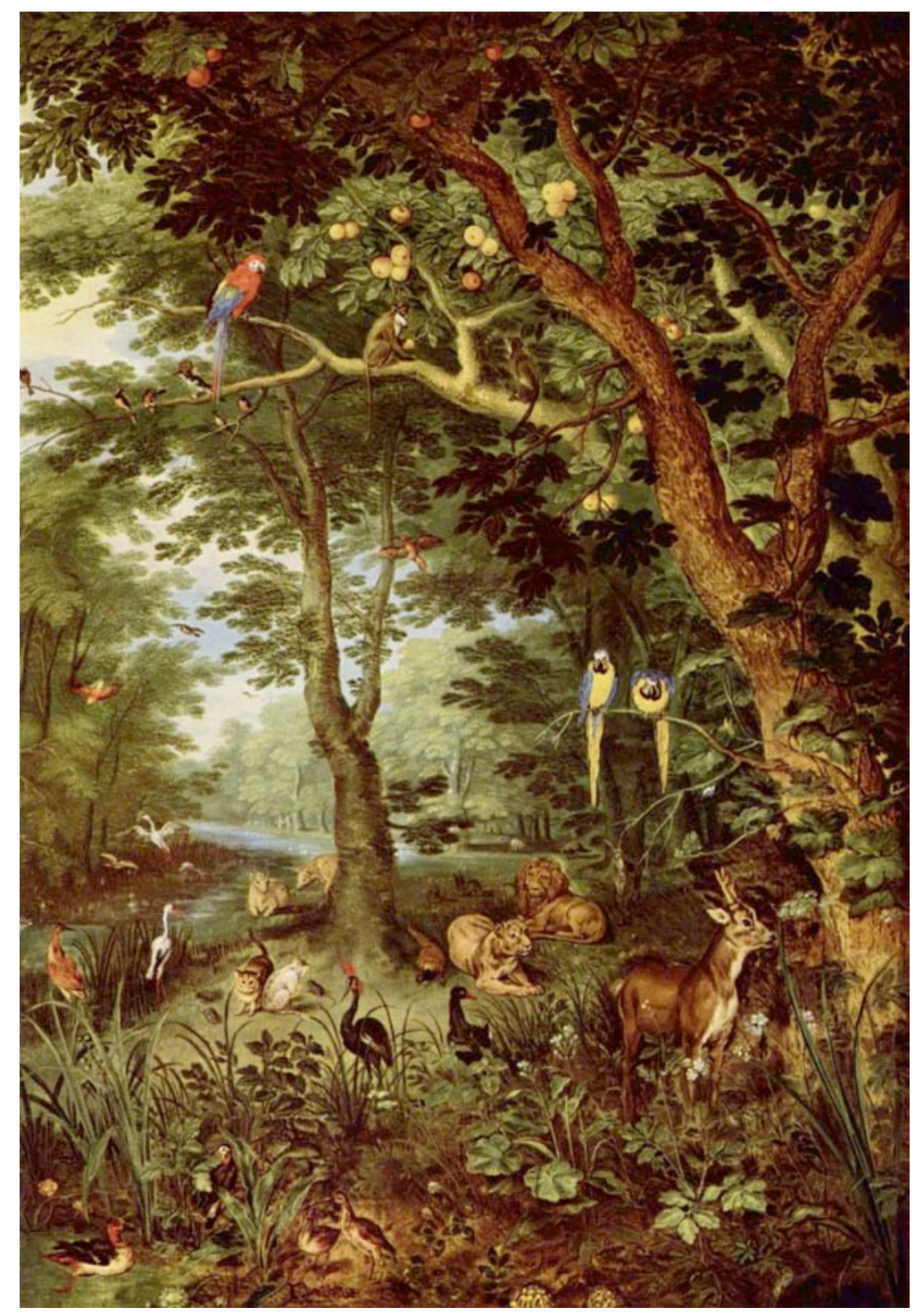

Fig. 31 Jan Brueghel - "Paraíso",1620

óleo sobre madeira, s/ dimensão

Gemaldegalerie, Berlim

Um segundo conceito de paraíso é aquele que proveio da idealização da América pelo europeu, que se forma através dos relatos dos cronistas que acompanharam os navegadores no período de chegada à América, entre os séc. XV e XVI.

Rebecca Parker Brenen (2010), escritora americana especialista em história da arte holandesa do séc. XVII, aborda as peculiaridades sobre o 
conceito de paraíso a partir das obras de Albert Eckhout (1607-1666), pintor de retratos e de naturezas mortas, e Frans Post (1612-1680) especialista em paisagens e que integraram a comitiva holandesa em seu período como colonizadores do território brasileiro.

Albert Eckhout criou um colorido autêntico, presente em seus retratos etnográficos, pela diversidade da cor da pele dos diversos grupos étnicos: portugueses, brasileiros, mamelucos, judeus, mestiços, africanos, mulatos e indígenas, principalmente os Tupinambá. Essa riqueza cromática também está presente na variedade da fauna e da flora retratadas. Busquei trazer para minhas telas este encantamento presente na obra de tais artistas, tentando decifrá-lo, por meio de elementos e procedimentos inusitados, por sua abundância de matizes cromáticos, instigada pelo impacto daquelas paisagens.

Em 1636, Mauricio de Nassau, chefe da expedição holandesa, com o intuito de investigar a história natural, e impressionado com a quantidade de espécies animais e vegetais ainda desconhecidos dos europeus, incumbe estes artistas do registro pictórico e descritivo de animais, plantas e seres humanos no Brasil. Desta forma, são retratados corpos nus, jovens e saudáveis, frutas em abundância e diversificadas, animais que para os europeus eram exóticos. Essas obras de cunho etnográfico, botânico e histórico ajudaram a "criam a impressão de que o Brasil é um paraíso do novo mundo", ${ }^{31}$ visão essa que se difundiu no imaginário dos grandes centros de cultura europeus.

Outros pormenores significativos nessas obras são a pintura ou desenho dos penteados, jóias e ornamentos corporais que dão status ao retratado. Um mero detalhe por vezes possui um grande significado:

Seria tão somente com as representações de Albert Eckhout que a riqueza de cores e variedades surpreendente de plantas e animais do Brasil, assim como a beleza e o 'exotismo' de seus

31 brienen, Rebecca Parker, Albert Eckhout: Visões do Paraíso Selvagem: obra COMPLETA, Pedro Correa do Lago (coord.) ; trad. Julio Bandeira - Rio de Janeiro: Capivara, 2010 - pag. 16. 
povos, puderam ser preservadas, estudadas e, eventualmente, possuídas por aqueles do outro lado do Atlântico. ${ }^{32}$

Esses pintores construíram por meio de suas obras uma visão européia do Brasil colonial seiscentista. Retratando com primazia o novo mundo, considerado um paraíso pela abundancia da fauna e flora, mostraram a fecundidade local. Uma paisagem cheia de cheiros, sabores, texturas e sons desconhecidos até então. Nesses pintores a exuberância se torna sinônimo de paraíso, que observo referencia na tela Pantanal (fig. 3) e remete às "tapeçarias confeccionadas pela manufacture de gobelins, em Paris, baseadas em cartões confeccionados segundo os desenhos e pinturas de Echkout". ${ }^{33}$ Perceber esses aspectos é fundamental para penetrar no significado da obra.

Optando pela experimentação em pintura, o objetivo na nova série "Paraísos" é produzir algo original, não pela a idéia do novo porque recente e atual, mas como uma criação que contribua para outra abordagem quanto à produção de retratos e paisagens.

No séc. XVII os grandes senhores europeus colecionavam animais incomuns, o que thes conferia status, e propiciou a construção de jardins zoológicos. A primeira grande paisagem que realizei se intitula: "Zoológico I", $200 \times 400 \mathrm{~cm}$, que configura um espaço natural em que animais vivem todos soltos, em harmonia. Em paralelo hoje possuímos o animal na obra.

A terceira abordagem de Paraíso é dada pela psicanálise, permite estender o significado, pois é visto como algo próprio de cada ser humano, que forma um sentido, um discernimento, que forma uma verdade, que nem sempre está ligado ao prazer. Algo particular, que deixa de ser externo para fazer parte da intimidade e esta representado na obra "Paraíso IV" (fig. 32), onde esta retratada uma figura sendo desvelada dentro de outra. Este paraíso como algo

\footnotetext{
32 Idem, ibidem. P.21.

${ }^{33}$ Idem, ibidem. P.28.
} 
que independe do bem e do mal, da moral, não está ligado à noção do paraíso como promessa de vida eterna, onde o Céu seria a recompensa pela bondade e o Inferno o pagamento dos pecados (o mal), mas como algo pessoal.

O Paraíso está na nossa mente e pode ser qualquer lugar. Não procuro retratar o mito no que tem de essencial e eterno, mas no que pode exibir de transitoriedade e imanência.

Nesta série "Paraísos", a Eva surge como um novo corpo pictórico, criado a partir de uma foto minha (Fernanda Eva), e me torno personagem na tela.

Alguns destes caminhos podem me levar ao Paraíso. Faço poses e piruetas me materializando em pintura, crio um estranhamento nos tranquilos paraísos. Várias possibilidades de me retratar se abrem: eu, princesa, fada ou bruxa; espreitando ou participando; definitivamente entrando como a Eva que quer habitar um novo mundo. Dentro dessa temática ainda surgem novas idéias de cenas para se contar as histórias.

Tratando ainda do relacionamento das personagens humanas com animais, surgem novos personagens em cena, como o dinossauro na obra "Paraíso IV" (fig. 32) remetendo a um tempo muito distante, trazendo uma sensação de primitividade ao imaginário do ser humano. Dinossauros e o homo sapiens nunca conviveram, mas aqui eles coabitam em harmonia. Tento concretizar em imagens uma sensação que, verbalmente, poderia ser exposta assim: "dentro de mim há um pedido para que um dinossauro me leve pelas mãos para um local mais primitivo". Outra interpretação é que pode haver um enfrentamento de meus próprios monstros. A realização de uma obra, como já citei, é intuitiva, e acabada abre várias possibilidade de leituras. O uso de velaturas e manchas faz surgir um novo universo pictórico.

Na obra "Paraíso III" (fig. 33) pode-se notar claramente na forma em que me retrato que me coloco como um animal selvagem em cena. Crio uma intimidade com o gorila retratado, querendo sugerir a criação do mundo. A serpente nos espreita, figura emblemática na perda do paraíso, no imaginário cristão, mas por enquanto tudo esta calmo. Há flores no jardim do éden. 
Tanto as questões temáticas como as técnicas mudaram no decorrer do processo. Observando essa tela, percebi que passei a utilizar a linha, o que nas paisagens anteriores não existia. Aqui, questões de feitura são aceitos como qualidades inerentes ao processo: com a libertação da exatidão da pincelada, experimento outros modos de realizar a pintura. Com isso há uma abertura para a imaginação do espectador completar o sentido da obra.

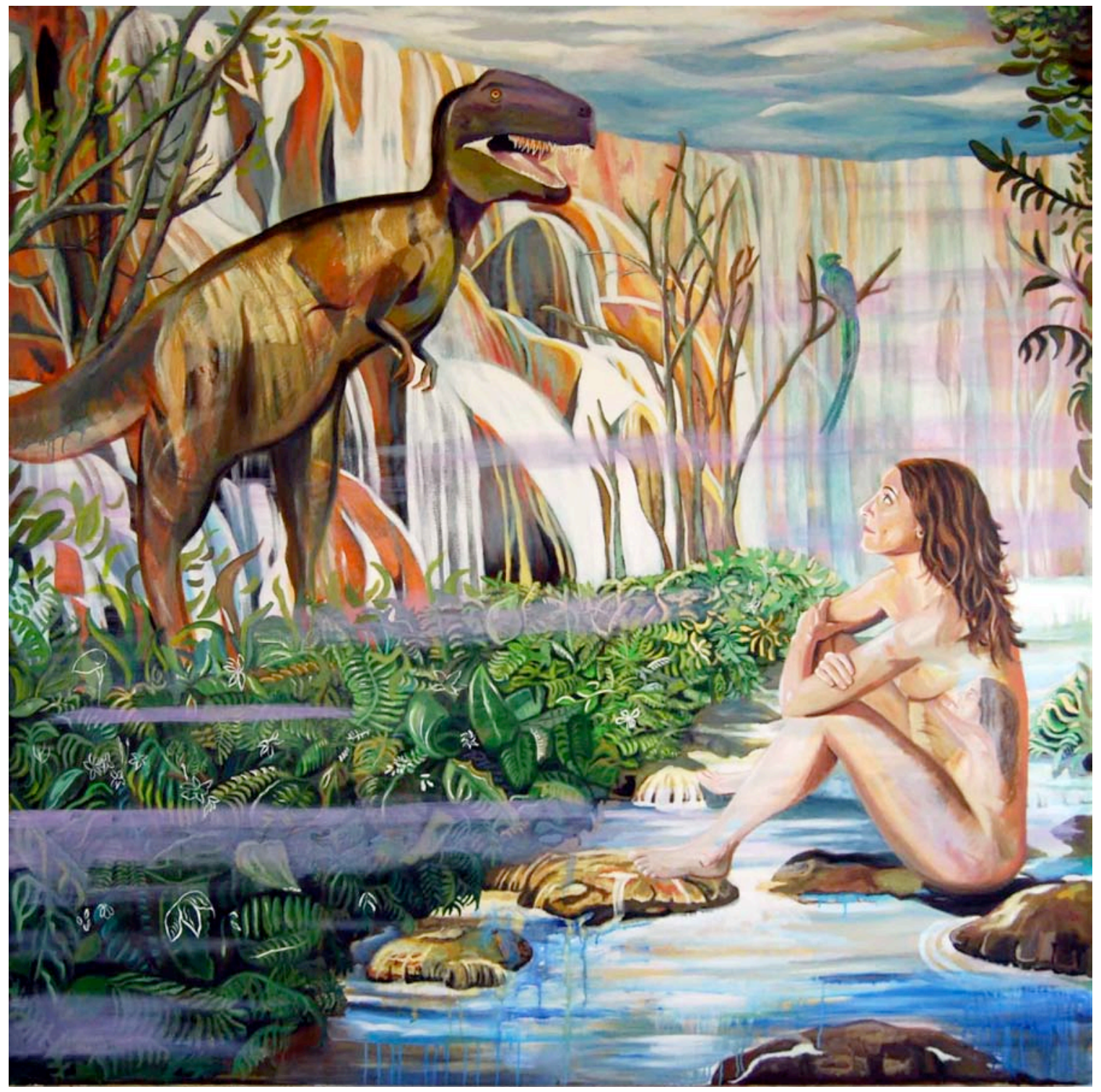

Fig. 32 - Fernanda Eva - "Paraíso IV", 2011

Acrílica sobre tela, $190 \times 190 \mathrm{~cm}$

Começo a utilizar a tinta mais aguada, deixando-a por vezes escorrer pela tela. A textura da tela passa a participar da obra. O excesso de tinta escorre das 
figuras e as tornam enevoadas e instigantes, escondendo-as, como no "Paraíso I" (Fig. 34), propondo ao observador que decifre a forma que se constituiu naquele espaço.

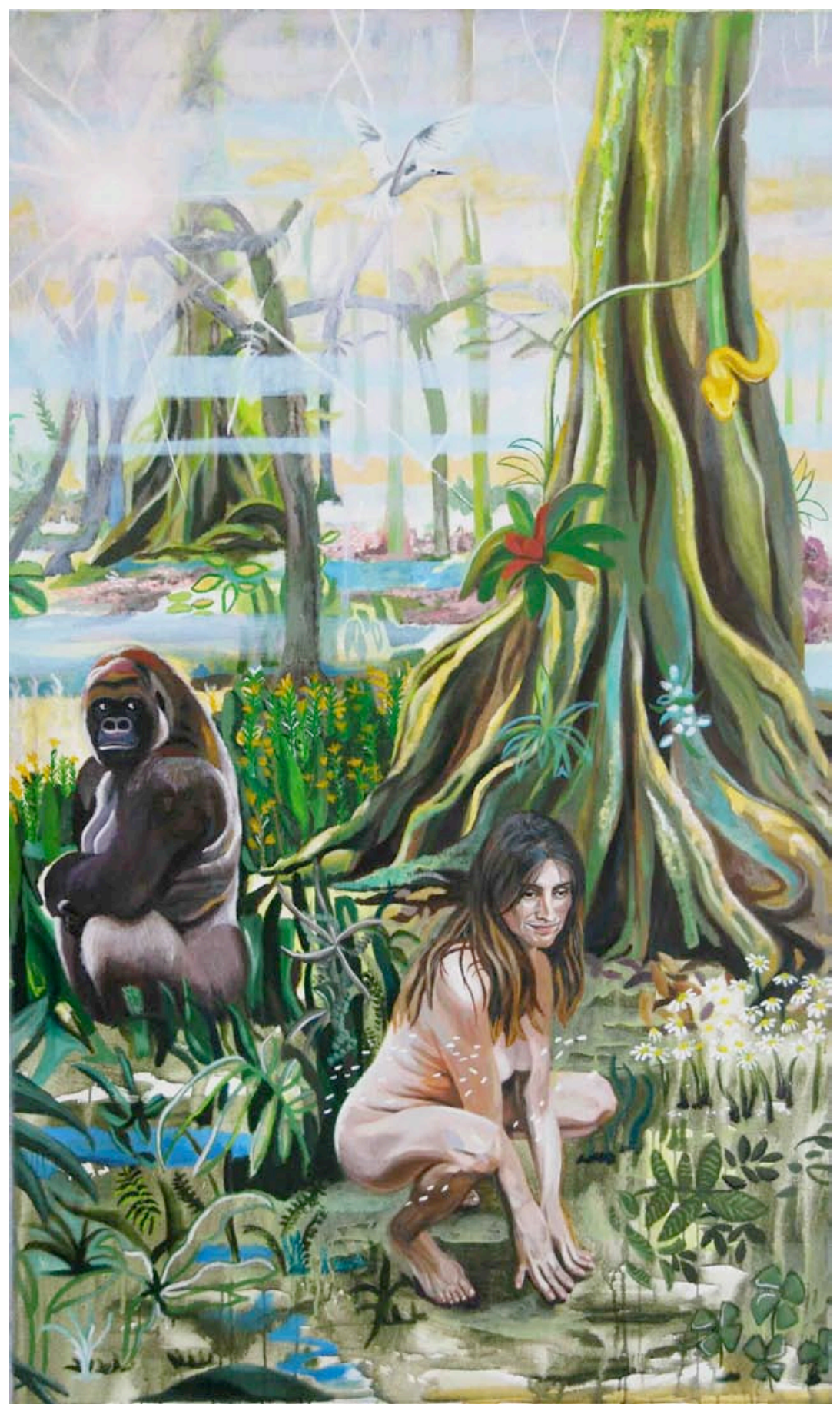

Fig. 33 - Fernanda Eva - "Paraíso III", 2010

Acrílica sobre tela, $190 \times 110 \mathrm{~cm}$ 
Praticando o uso da linha e suas variações, se estabelece um jogo entre o linear e o pictórico. Normalmente a pintura não utiliza a linha tão bem definida, que apareça destacada e variada como em desenho, pois o uso da linha como contorno da imagem torna a imagem dura. Tradicionalmente, em pintura as bordas são esfumadas para rebaixar essa linha intransigente. Mas nestes trabalhos, a linha surge para percorrer os elementos da composição. Percurso sutil, quando pelas bordas, ou destacado, quando sobre as formas. Essas linhas vão criando principalmente espaços sem preenchimento, vazios, sobreposições de espaços crus, neutros. Com isso, a obra convida o espectador a aproximarse e penetrar nesse campo imaginário.

Proponho um jogo de revelação a partir de sobreposições de camadas, onde podem vir à tona muitos campos de significação. Trata-se de uma montagem onde paisagens criam ambientes novos, ora com obtenção de profundidade, ora negando totalmente a perspectiva. Há uma abertura do olhar para três dimensões, buscando um novo enquadramento e novos ângulos para a representação dos personagens, conferindo-Ihes movimento. A mistura, em cena, de todos os artistas de referência, gera este novo ambiente-paisagem, que promove uma variedade de estilos dentro de uma única obra.

Na série "Retratos Gigantes" utilizo cores calmas, em tonalidades pálidas, em imagens enevoadas, brumas que flutuam como que num ambiente onírico, com o propósito de criar sensações místicas, fantasmagóricas, experimentadas nas fotografias, mas com uma atmosfera de fábulas, com um fundo construído de tintas manchadas e ralas. Nessa série, as figuras se destacam pelo modo bem definido com que são pintadas, em contraste com seu entorno, como já era realizado nos animais retratados nas primeiras pinturas de paisagens.

Para a produção destas telas me inspirei nas obras do artista Lucian Freud, tentando expor os sentimentos da alma humana, mas não através do outro e sim de mim mesma, despindo-me de idéias pré-concebidas.

Segundo Teixeira Coelho, um dos motivos do início do auto-retrato como prática na história da pintura foi "o esforço do artista para que o vissem como 
aqueles que ele próprio retratava, isto é, como membro das classes altas; um outro aspecto é a atração narcisista pela própria imagem; tentativa de sair de si mesmo, para enfim ver-se melhor, ou a simples comodidade de ser o modelo disponível". ${ }^{34}$ Ao me retratar nas obras talvez eu tivesse a intenção de conseguir compartilhar das sensações daquele pequeno paraíso e experimentar a pureza selvagem, não verbal e irracional daqueles animais.

Na tela "Paraíso II" (fig. 35) eu observo os animais e, pictoricamente, "ganho" asas. Como substrato filosófico e psicológico da composição, busquei simbolizar a busca do homem contemporâneo por modo de vida mais harmonioso, já que não há mais lugares tão tranqüilos e paradisíacos: os paraísos de Eckhout permanecem apenas em suas obras, como que cristalizados.

Na tela Paraíso V (fig. 36) a Eva encontra seu Adão e é retratado em um momento de plenitude, quietude, podendo até dormir com um animal feroz como o tigre, imagem retirada da obra "La Douleur Du Pacha" 1885 de Jean-Léon Gerome (1824-1904) exposta no Museu D'orsay em Paris.

$\mathrm{Na}$ obra Paraíso VI (fig. 37) há utilização de imagens com forte simbologia. Há um anjo que guarda a Eva no Paraíso, um Cupido que é um Deus romano símbolo do amor, que ironizo ser o agente do amor de Eva por Adão; surge um gato por entre as folhas, símbolo da passagem desta vida para outra; a árvore quase que centralizada, representando a árvore proibida que remete à sabedoria e à vida eterna.

Nas obras "Paraíso II, III, IV, V e Vl" ocorre uma mudança na retratação do olhar da figura representada. Em todas as obras anteriores, quando há personagens, um deles sempre tem o olhar voltado para o espectador. A partir desta obras não a mais este olhar. Os personagens ou olham para dentro da cena, ou estão dormindo, ou seja, se voltam para a representação na tela. Não

\footnotetext{
34 COELHO, Teixeira. "Olhar e ser visto". Denis Donizetti e Bruza Molino. São Paulo: Comunique, 2008. P.82.
} 
há mais o olhar que convidava o espectador, mas que também por vezes 0 inibia. O espectador agora é convidado a apreciar sem ser notado.

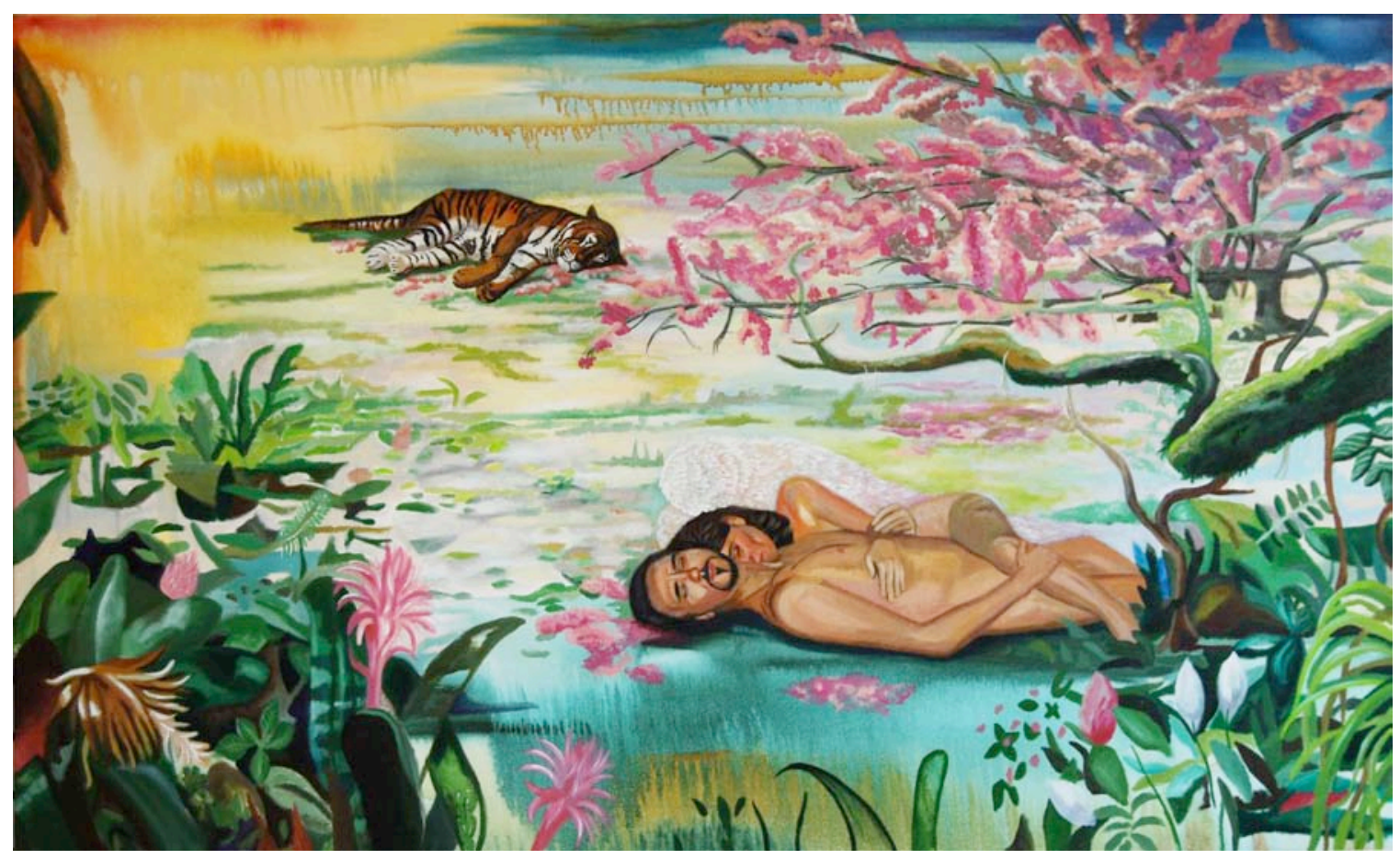

Fig. 36 - Fernanda Eva - "Paraíso V", 2011

Acrílica sobre tela, $110 \times 180 \mathrm{~cm}$

$\mathrm{Na}$ esteira das idéias correntes do surrealismo, afirma Max Ernest: "Assim como o papel do poeta desde a celebre carta do vidente consiste em escrever sob o ditado do que se pensa, do que se articula dentro dele, o papel do pintor é cercar e projetar o que dentro dele se vê". ${ }^{35}$ As obras de arte tornam-se um testemunho da vida interior. $O$ artista reflete em sua obra a vida em seu entorno, como a prática artística desvenda seu interior e, assim, do ser humano.

\footnotetext{
${ }^{35}$ ERNEST, Max. In MERLEAU-PONTY, 2004, p. 21.
} 


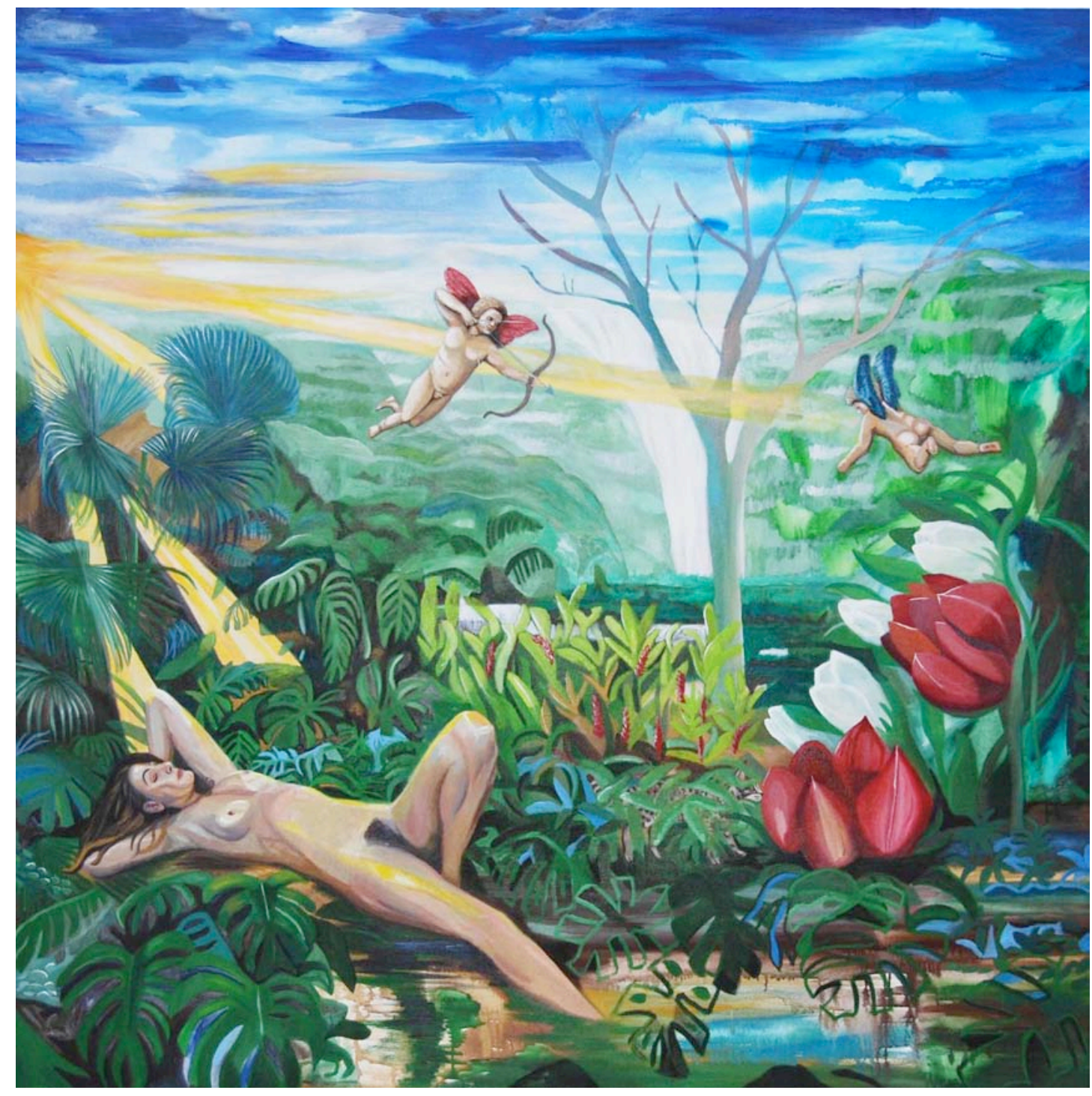

Fig. 37 - Fernanda Eva - "Paraíso VI”, 2011

Acrílica sobre tela, $180 \times 180 \mathrm{~cm}$ 


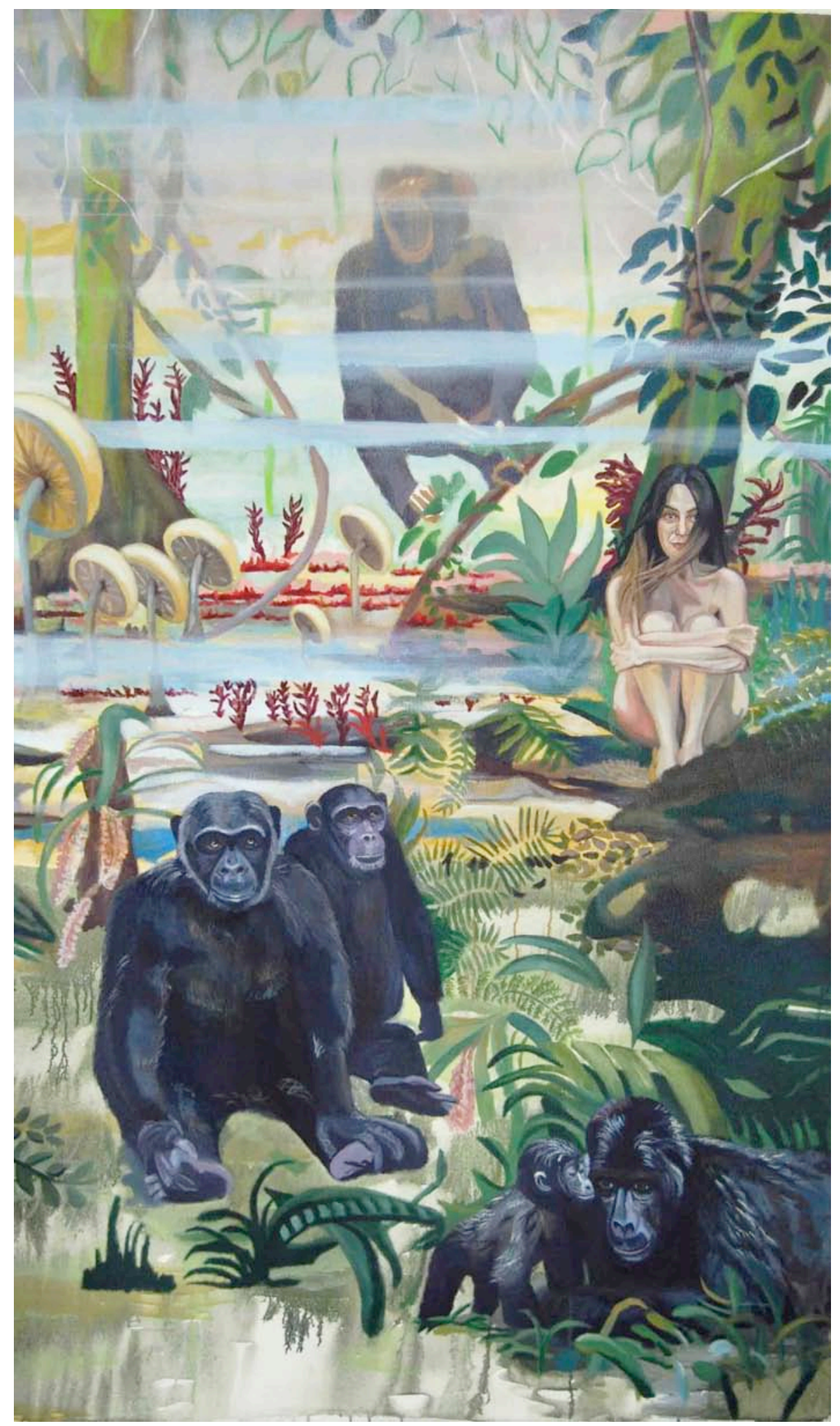

Fig. 34 - Fernanda Eva - "Paraíso I", 2010

Acrílica sobre tela, $190 \times 110 \mathrm{~cm}$ 


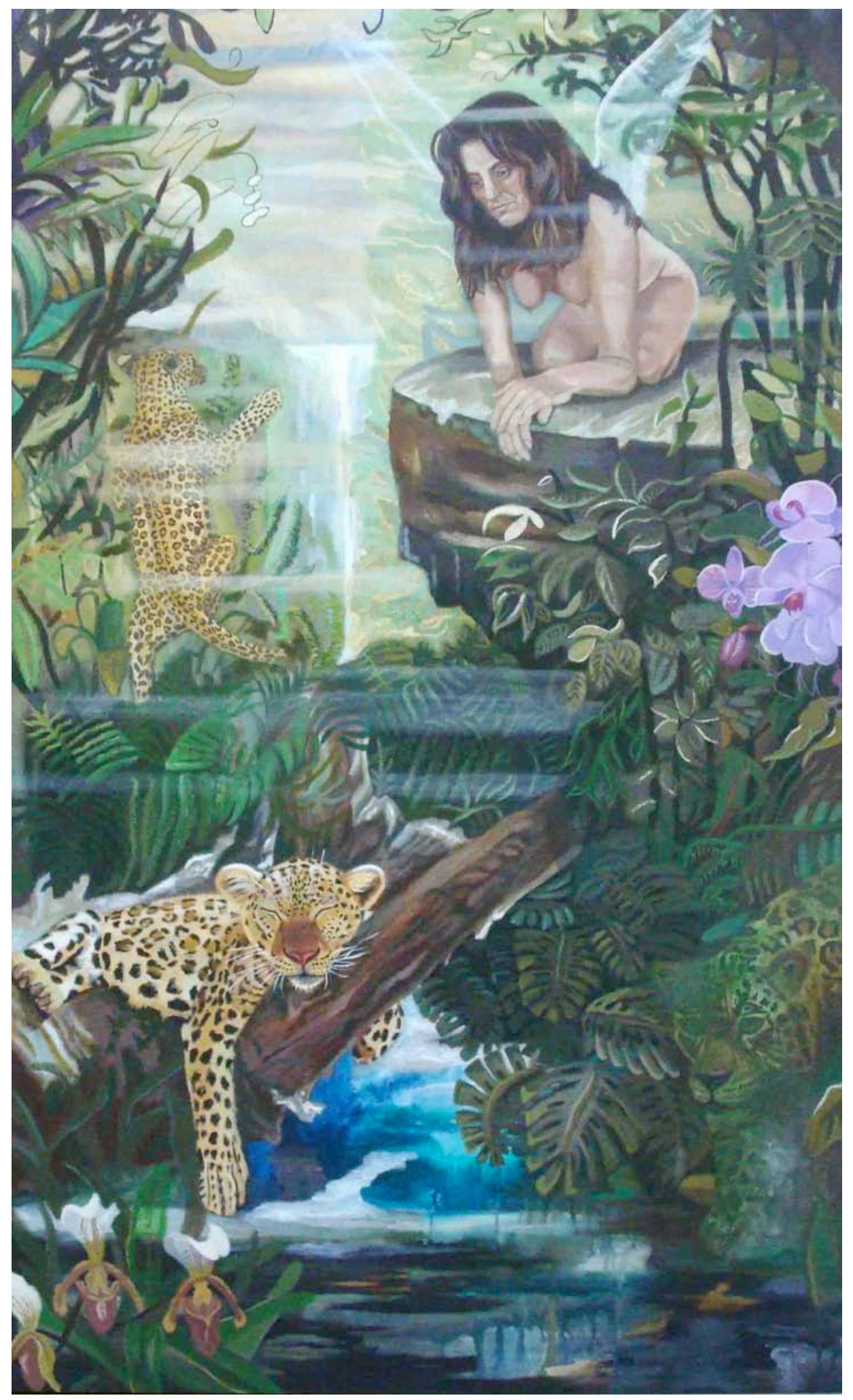

Fig.35 - Fernanda Eva - "Paraíso II", 2010

Acrílica sobre tela, $180 \times 100 \mathrm{~cm}$ 


\section{8 - CONSIDERAÇÕES FINAIS}

A Pintura é um gênero de arte que teve início com os homens préhistóricos, especificamente os homens do paleolítico, que usavam pigmentos corantes para inscrições de símbolos nas pedras das cavernas. Essa prática estava provavelmente relacionada a rituais de magia, que visavam capturar e dominar sua presa, por meio destes desenhos.

Com o passar dos séculos, a presa que o artista quer capturar com a obra tornou-se outra. $O$ ritual da pintura não objetiva mais capturar o animal: agora 0 foco é o público. A pintura quer sensibilizar o próprio homem, resgatar o humano que há em nós, através da retratação de paisagens, pessoas e animais.

A pintura é um oficio solitário. A discussão das questões na hora de sua realização, diferente de outras áreas de artífices, se dá dentro do próprio pintor, e ele sozinho responderá a essas questões. Não tendo o feedback de alguém no momento da realização, o seu resultado só será avaliado quando apresentado ao observador, ao público.

Assim, expor a produção ao público é parte inerente ao processo de produção nas Artes Visuais. No texto "O processo criador" Marcel Duchamp afirma que o espectador faz o quadro:

"O artista nunca tem plena consciência de sua obra: entre as suas intenções e sua realização, entre o que quer dizer e o que a obra diz, há uma diferença. Essa 'diferença' é realmente a obra. Portanto, o espectador não julga o quadro pelas intenções de seu autor, mas pelo que realmente vê; esta visão nunca é objetiva: o espectador interpreta e 'refina' o que vê". ${ }^{36}$

Observando a minha exposição "Quem invade o Paraíso?", realizada no Centro Cultural São Paulo, organizada com as pinturas da série "Retratos

\footnotetext{
36 - DUCHAMP, M. In: PAZ, 2008, p.60.
} 
Gigantes", pude perceber a reação do público, como critério complementar para avaliar os "erros" e "acertos" da produção. Nessas telas procurei refletir sobre a relação entre as personagens e o próprio espectador, propondo ao público perceber seu entorno, através da própria montagem da sala. As obras foram espalhadas uniformemente, configurando um espaço de contemplação onde o visitante foi convidado a sentar-se em bancos para olhar com calma as pinturas.

Jorge Menna Barreto, curador da exposição, me chamou a atenção para o seguinte fato: tamanho foi entusiasmo com o trabalho, que levou os visitantes a fotografar-se diante das telas, o que gerou uma maior aproximação com o público. Menna Barreto ainda afirma: "fotografar-se diante de uma imagem é um ato frequente em viagens, o impulso sinaliza que ali há algo da ordem da experiência que deve ser registrado, algo de uma expansão na sensibilidade e um afetar que merecerão um segundo olhar". ${ }^{37}$ As obras de arte ativam os nossos sentidos e uma boa obra é aquela que nos faz sair tocados emocionalmente ao vê-la. Pensando assim, creio que estas obras cumpriram sua função.

De acordo com Duchamp, "o valor de um quadro ou qualquer outra criação de arte se mede pelos signos que nos revela e pelas possibilidades de combiná-los que contém. Uma obra é uma máquina de significar. Só o espectador pode pôr em movimento o aparelho de signos que toda obra é". ${ }^{38} \mathrm{~A}$ obra de arte propicia ao homem uma infinidade de leituras e não importa quantas o espectador consiga fazer: o mais importante é colocá-lo em contato com a obra, esperando com isto alguma reação que gere uma transformação interna.

Os artistas têm o poder de representar e retratar o período em que vivem. O meu universo particular, o lugar onde vivo, as pessoas com quem convivo fazem com que eu seja exatamente quem eu sou. Criam também minha

\footnotetext{
37 - BARRETO, Jorge Menna. Catalogo de Exposição do Centro Cultural São Paulo, 2009

38 - DUCHAMP, M. In: PAZ, 2008, p. 61
} 
experiência estética, trazendo em cada obra as minhas memórias e meus sentimentos o que pode ser notado nas séries aqui apresentadas, onde retrato amigos e a mim mesma.

Colocar as pessoas em contato com algo novo, assim como fizeram os pintores Albert Eckhout e Frans Post, é uma das funções da arte, assim como propiciar um conhecimento sensível através da matéria e criar noções de espaço e tempo.

Buscando alguma originalidade, pretendi transportar o espectador a um novo universo, calmo, diferente da realidade urbana do século XXI. Por isso os "Paraísos" na última série se tornaram mais fantasiosos, saindo da realidade, das tristezas, das neuroses da vida urbana e tornaram-se um lugar descontraído.

Matisse escreveu:

"Sonho com uma arte de equilíbrio, de pureza, de tranquilidade, sem temas inquietantes ou preocupantes, uma arte que seja, para qualquer trabalhador cerebral, quer o homem de negócios, quer o homem cultivado, por exemplo, um lenitivo, um calmante mental, algo como uma boa poltrona onde ele pode relaxar 0 cansaço físico." 39

Seguindo esta idéia minhas obras apresentam formas que querem agir na atmosfera da psique para transportar o espectador até um reino inventado, um lugar imaginário. Meu objetivo nestas obras é propô-las como veículo de sugestão de sonho, de realização, de prazer, despertando mais um novo sentimento, seja hilariante, seja de desejo, seja onírico. Ao invés de propor uma reflexão profunda sobre a arte, apesar de trabalhar as questões técnicas da pintura, que se voltam também para o expert, a minha produção é focada em tocar o homem comum, o espectador não especializado.

\footnotetext{
${ }^{39}$ Matisse, Henri/ Escritos e reflexões sobre arte, trad. Denise Bottmann, São Paulo: Cosac Naif, 2007. p. 47.
} 
Esperei, por fim, que não houvesse a pergunta do público: "o que o artista quis dizer com isto?" mas sim que ele estivesse desarmado diante dos possíveis significados que o trabalho possa ter e livre para sentir o que a obra possa the despertar.

Usando a imaginação criadora, apresento um mundo subjetivo, decorrente da reflexão sobre a complexidade e a singularidade do homem contemporâneo, com outras dimensões, um "Paraíso" para que nele o espectador se sinta reconfortado.

Tornou-se perceptível uma mudança na execução das pinturas, que a princípio na série "Paisagens" eram de um colorido muito forte e no decorrer do período de pesquisa passaram a ter uma cor mais amena, se tornaram mais imaginativas, com uma feitura mais trabalhada e solta.

Esta dissertação de mestrado propiciou uma reflexão maior para a elaboração de novas obras, para percorrer os caminhos labirínticos de escolhas para esta ou aquela imagem. Acredito que a pintura ainda seja um veículo de comunicação privilegiado entre os homens, sendo o que possibilita maior criatividade e originalidade, onde me encontro mais apta para expressar as minhas impressões sobre as pessoas, a vida e o mundo.

REFERÊNCIAS BIBLIOGRÁFICAS 
ARGAN, G. C. "Arte Moderna". Tradução Denise Bottmann e Frederico ??? 4" Reimp. São Paulo: Companhia das Letras, 1992.

BAUDELAIRE, Charles. "A paisagem". Salão de 1859. In LICHTENSTEIN, J. A Pintura. V. 10. São Paulo: Ed. 34, 2006.

BRIENEN, R. P. "Albert Eckhout: Visões do Paraíso Selvagem: Obra completa". Pedro Correa do Lago (coord.); trad. Julio Bandeira - Rio de Janeiro: Capivara, 2010.

DANTO, Arthur Colerman. "Após o fim da arte: a arte contemporânea e os limites da história". Tradução Saulo Krieger. São Paulo: Odysseus Editora, 2006.

GROMBRICH, Ernst Hans Josef. "Arte e llusão: um estudo da psicologia da representação pictórica". Tradução Raul de Sá Barbosa, 3 edição. São Paulo: Martins Fontes, 1995.

HAUSER, A. "História social da arte e da literatura". São Paulo: Martins Fontes, 1995.

HEARTNEY, E. "Pós-Modernismo". São Paulo: Cosac \& Naify / Tate Gallery Publishing, 2002.

HUYSMANS, Jori-Karl. "Goya e Turner”. A cor moderna. In LICHTENSTEIN, J. A Pintura. V. 9: O desenho e a cor. São Paulo: Ed. 34, 2006.

LEIRNER, S. "Arte e seu tempo”. São Paulo: Ed. Perspectiva, 1991.

LEITE, Rui Moreira. Modernismo e Vanguarda: o caso Flávio de Carvalho. "Revista Estudos Avançados". V. 12, n. 33, São Paulo, maio /ago.1998.

MARTINS, C. A vida atribulada de Dante Aligheri, In "A Divina Comédia". São Paulo: Ed. Itatiaia / Ed. da Universidade de São Paulo, 1976. 
MATISSE, Henri. "Escritos e reflexões sobre arte". Tradução Denise Bottmann. São Paulo: Cosac Naif, 2007.

MERLEAU-PONTY, Maurice. "O olho e o espírito: seguido de A linguagem direta e as vozes do silêncio e A Dúvida de Cézanne”. Tradução Paulo Neves e Maria Ermantina Galvão Gomes Pereira. São Paulo: Cosac \& Naify, 2004.

PAZ, Octavio. "Marcel Duchamp, ou O castelo da pureza". Tradução Sebastião Uchoa Leite. São Paulo: Perspectiva, 2008.

PILES, Roger de. "Da paisagem". Curso de Pintura por Princípios. In LICHTENSTEIN, J. A Pintura. V. 10. São Paulo: Ed. 34, 2006.

ROSENBERG, Harold Objeto ansioso. Tradução Vera Pereira. São Paulo: Cosac \& Naify, 2004.

SCHAPIRO, Meyer. "Meyer Schapiro: Impressionismo: reflexões e percepções”. Tradução Ana Luiza Dantas Borges São Paulo: Cosac Naify, 2002.

SENNETT, Richard. "O Artífice". Tradução de Clovis Marques. Rio de Janeiro: Record, 2009.

- STABENOW, Cornelia. "Henri Rousseau". Tradução: Ruth Correia. Germany: Taschen, 2001.

\section{CATÁLOGOS:}

CHIODETTO Eder e MONTEROSSO, Jean-Luc. "A invenção de um mundo". Coleção da Maison Européenne de La Photographie, Paris. Tradução: Sieni Campos. São Paulo: Itaú Cultural, 2009. 
COELHO, Teixeira. "Olhar e ser visto". Denis Donizetti e Bruza Molino. São Paulo: Comunique, 2008.

COSTA, Cacilda Teixeira da. "Retrospectiva Wesley Duke Lee”. São Paulo: MASP; Rio de Janeiro: Centro Cultural Banco do Brasil, 1992/1993.

FREMAUX, Thierry, PAINI, Dominique e LAMOTTE, Jean-Marc "Autocromos Lumiere: o tempo da cor”. Organizadora: Ariadne G. Mattei Manzi. Tradução Haci Maria Longhi Farina. Curitiba: Museu Oscar Niemeyer, 2009.

“Lucian Freud paintings". London: Thames \& Hudson, 2000.

"Paradise Lost / Paradise Regained: American Visions of the New Decade, La 41 biennale di venezia 1984". United States Pavilion. The New Museum of Contemporany Art, New York City.

\section{VIDEO}

"Por que o artista contemporâneo ainda pinta?”, 8', Fernanda Eva , São Paulo: 2008 - disponível no canal do WWW.Youtube.com/fernandaeva:

http://www.youtube.com/watch?v=N_EfbfSPXZU 